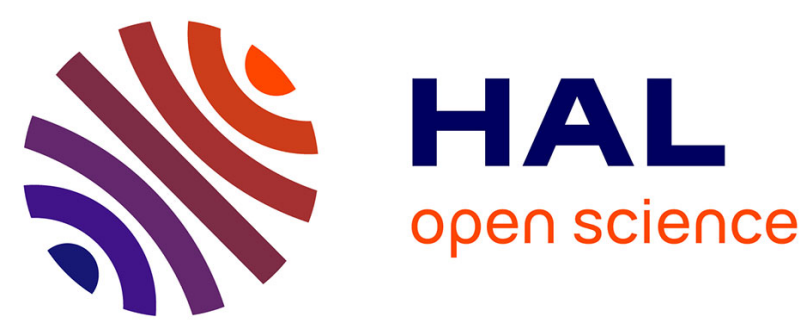

\title{
Reliability of very low-grade metamorphic methods to decipher basin evolution: Case study from the Markstein basin (Southern Vosges, NE France)
}

Sébastien Potel, Tatiana Maison, Marine Maillet, Anta-Clarisse Sarr, Michael Patrick Doublier, Ghislain Trullenque, Rafael Ferreiro Mählmann

\section{To cite this version:}

Sébastien Potel, Tatiana Maison, Marine Maillet, Anta-Clarisse Sarr, Michael Patrick Doublier, et al.. Reliability of very low-grade metamorphic methods to decipher basin evolution: Case study from the Markstein basin (Southern Vosges, NE France). Applied Clay Science, 2016, 134, Part 3, pp.175-185. 10.1016/j.clay.2016.10.003 . hal-03155281

\section{HAL Id: hal-03155281 \\ https://hal.science/hal-03155281}

Submitted on 1 Mar 2021

HAL is a multi-disciplinary open access archive for the deposit and dissemination of scientific research documents, whether they are published or not. The documents may come from teaching and research institutions in France or abroad, or from public or private research centers.
L'archive ouverte pluridisciplinaire HAL, est destinée au dépôt et à la diffusion de documents scientifiques de niveau recherche, publiés ou non, émanant des établissements d'enseignement et de recherche français ou étrangers, des laboratoires publics ou privés. 
Reliability of very low-grade metamorphic methods to decipher basin evolution: case study from the Markstein basin (Southern Vosges, NE France)

Sébastien Potel ${ }^{1}$, Tatiana Maison ${ }^{1}$, Marine Maillet ${ }^{1}$, Anta-Clarisse Sarr ${ }^{1}$, Michael Patrick Doublier ${ }^{2}$, Ghislain Trullenque $^{1}$ and Rafael Ferreiro Mälhmann ${ }^{3}$

${ }^{1}$ B2R, Institut Polytechnique LaSalle Beauvais, Geosciences Department, 19 Rue Pierre Waguet, F-60026 Beauvais(sebastien.potel@lasalle-beauvais.fr); ${ }^{2}$ Geoscience Australia, Resources Division, Cnr Jerrabomberra Avenue and Hindmarsh Drive, Symonston 2609, ACT, Australia; ${ }^{3}$ Technische Universität Darmstadt, Institut für Angewandte Geowissenschaften, Schnittspahnstraße 9, D-64287 Darmstadt, Germany

\section{Abstract}

Low- and very low-grade metamorphic studies investigating the alteration and reaction progress of clay minerals are powerful tools to decipher the thermal evolution of sedimentary and inverted meta-sedimentary basins. Sheet silicates such as illite and chlorite are very common in sedimentary basin sequences. They can be used to determine the grade of diagenesis and low-temperature metamorphism as measured through the XRD: illite Kübler-Index (KI; illite "crystallinity" in older literature) and the chlorite Árkai-Index (Ál; chlorite "crystallinity" in older literature), respectively. Although the Ál method is considered to be slightly less sensitive than the KI method, a reliable correlation between both methods is often observed in metamorphic domains with a uniform heat-flow history and minor tectono-structural complexity. Complementary to these methods, the K-white mica $b$ cell dimension provides a robust estimate of pressure facies reached in very low- to low-grade temperature domains.

Here, we present a case-study from the Markstein basin located in the Southern Vosges. The lithostratigraphic units in the basin are characterized by deep marine flysch sequences of Upper Devonian to Upper Visean age and volcano-clastic sediments, respectively. The Markstein basin is surrounded by granitoids with intrusion ages between 340 and $326 \mathrm{Ma}$. A 
previous study showed orogenic deformation characterized by regional folding, and a contact metamorphism found in an outer halo of the granitoids up to $1500 \mathrm{~m}$ away from the contact (delineated by the occurrence of biotite and andalusite). Here we present a multidisciplinary study combining mineral assemblages, illite and chlorite "crystallinity indices", and K-white mica $b$ cell dimension. Our approach allows to (i) map in (great) detail the areal extent of both regional/burial metamorphic and contact metamorphic domains; (ii) reveal the metamorphic zonation within both domains; and (iii) better constrain regional/burial and contact metamorphic history. The contact metamorphic domain is characterized by the occurrence of biotite and/or actinolite and low K-white mica $b$ cell dimensions, whereas the zone of incipient orogenic metamorphism yields $\mathrm{KI}$ and Ál values of the high-grade diagenesis and anchizone with intermediate K-white $b$ cell dimensions.

\section{Keywords (6 keywords)}

Clay minerals; very low-grade metamorphic petrology; chlorite geothermometry; Kübler Index; basin evolution; Vosges

\section{Introduction}

The metamorphic grade of rocks of "very low- and low-grade metamorphism" (as follows the term will include also grade of diagenesis) is difficult to assess. The classical methods applied are the so-called illite "crystallinity" and the vitrinite reflectance. The methods are dependent on several factors: while the dominant factor is duration of thermal metamorphism, they also depend on pressure and the kinetics in mineral and organic matter 
reaction progress, respectively. In metamorphic studies, contrary to the diagenesis research, the very low temperature range has been little considered due to few mineral-reaction isograds established (zeolites and phyllosilicates) and to diverse disequilibrium states in the rocks to be studied (Ferreiro Mählmann et al., 2012). For these reasons, most publications regarding the determination of grade of metamorphism deal with conditions above $300^{\circ} \mathrm{C}$ and the first occurrence of neo-formed metamorphic minerals with well defined reactionisograds such as biotite, chloritoid, and actinolite (Turner, 1968; Winkler, 1979; Bucher and Frey 1994). Basic methods developed in low-temperature petrology of sedimentary rocks applied in very low-grade studies use clay mineral indices. In this field, changes in the shape and sharpness ratio of the XRD $10 \AA$ illite peak are characteristic for changes in grade of incipient metamorphism. It is recognized that a steady increase in the height-to-width ration of the $10 \AA$ peak occurs with increasing diagenetic/incipient metamorphic grade (Weaver, 1961). Since Kübler (1967), illite "crystallinity" (IC) is used as a parameter, empirically related with the aggradation of illite (Ferreiro Mählmann et al., 2012). Temperature is believed to be the most important parameter affecting the IC (Kübler, 1967; 1968). As a rule, the IC value decreases (i.e., "crystallinity" increases) with increasing temperature (i.e. during sedimentary burial or tectonic overburden). The change in the IC value is attributed to: 1) a decrease of the proportion of swelling mixed-layers (especially at low-temperature diagenetic conditions); 2) an increase of the mean thickness of crystallites, often caused by a decrease in the amount of defects affecting the coherency of layer-to-layer bonding; 3) a decrease of lattice strain of crystallites (Merriman and Peacor 1999; Árkai et al., 2002). This is best illustrated in contact metamorphic aureoles and is also supported by a small number of hydrothermal experiments (Krumm, 1984). In addition, some crystal-chemical clay parameters, like the measurement of the K-white mica $b$ cell dimension (Sassi, 1972; Sassi 
and Scolari, 1974) can be used to decipher the metamorphic evolution of the rocks. This method is used as an estimate of pressure facies reached in low-grade meta-pelitic rocks (Frey and Robinson, 1999). Recently, Potel et al. (2006) have shown that this method is less prone to reset than $\mathrm{KI}$ and the $\mathrm{K}$-white mica $b$ cell dimension preserved early neoformation conditions after a pluri-facies metamorphic evolution.

Therefore, it is recommendable to use a multi-method clay-mineral approach for deciphering orogenic histories and in general geodynamic scenarios and -if possible- a combined investigation of mineralogical and organo-petrological methods (Ferreiro Mählmann et al., 2012). The aim of the present paper is to test the reliability of the different methods generally used to study metamorphic series implying clay minerals in a pluri-facies metamorphic evolution (burial and contact metamorphisms).

\section{Geological Setting}

In the Vosges, two of the central European Variscan Zones can be distinguished (Kossmat, 1927): the Saxothuringian zone in the north and the Moldanubian zone in the central and southern part (Fig. 1), both separated by a major SW-NE trending steep dipping fault, the shear zone of Lalaye Lubine (LLSZ) (Edel and Fluck, 1989). The northern area represents the Saxothuringian part of the Vosges Mountains and consists of sedimentary and volcanic sequences of Precambrian (schists of Villé), Silurian (schists of Steige) and Devonian to Early Carboniferous age (Bruche valley and Bande-médiane occurrences), and a series of dioritic to granitic plutons. The central and southern, Moldanubian parts consist of very low- to highgrade metamorphic sequences that were intruded by numerous granitoid plutons (intrusion ages between $340+/-2$ and $345+/-2 \mathrm{Ma}$, Schaltegger et al., 1996). The metamorphic rocks intruded by these granitoids are divided in a upper, high-grade unit (granulites with garnet 
peridotites, leptynites, kinzingites and amphibolite facies paragneiss) and an underlying medium grade unit with migmatic paragneiss and anatectic orthogneiss with granite neosomes (Kalt et al., 1994; Kalt and Altherr, 1996). The southernmost area is divided into two main sedimentary basin, the Visean volcano sedimentary Markstein basin in the north and the Permian Giromagny basin in its south (Fig. 1).

In the Markstein basin, three sedimentary units can be distinguished (Jung, 1928): a northern allochtonous Markstein unit, and the southern autochtonous Oderen and Thann units. The Markstein unit is separated from the southern units by the Klippen Belt (Jung, 1928), which represent discontinuous exposures of serpentinized harzburgite, ophicalcite, gabbro, gneiss and conglomerate (Fig. 2). The Klippen Belt is interpreted as exhumed relicts from deep parts of small, marginal back-arc basins developed during closure of the Palaeozoic subduction (Skrzypek et al., 2012). The Markstein unit is formed by an Early Carboniferous siliciclastic turbidite sequence of flysch like rocks (up to $3500 \mathrm{~m}$ thick) consisting of interbedded pelites and greywackes (Gagny, 1962; Krecher, 2005; Krecher et al., 2007). The volcano-sedimentary rocks of the autochtonous units are of Lower to Upper Visean age. The base of the Oderen unit is characterised by a succession of carbonates (probably of Frasnian age) overlain by Fammenian sediments and Early Carboniferous pelites and greywacke (Skrzypek et al., 2012). The Lower to Middle Visean sediments are composed of inter-bedded pelites and distal fine grained turbidites together with an associated volcanism documented by spilites (Maas, 1988; Schneider, 1990; Hammel, 1996).

The Markstein unit is framed to the west, north and east by a granitic plutons and also intruded by syn-genetic microgranitic dikes (Gagny, 1968; Schaltegger et al., 1996) related to the "granite des Crêtes» by Gagny (1968). The contact is either a tectonic one formed by brittle faults and/or contact metamorphism as characterized by a secondary growth of 
biotites and hornblendes (Petrini and Burg, 1998). According to these authors, the contact metamorphism can be recognised in a outer halo up to $1500 \mathrm{~m}$ away from the intrusion contacts (based on the occurrence of microscopic and mesoscopic determined biotite).

The whole Markstein formation is affected by intense folding in the form of tight structures with a fold axis striking N130 to N140 (Fig.2). This fold axis orientation is in accordance to results by Petrini and Burg (1998). Folding produces intense cleavage in some places nicely visible in the more competent layer, as already noticed by these last authors.

\section{Materials and Methods}

\subsection{X-ray diffraction}

In pelitic rocks diagnostic minerals and mineral assemblages of the very low-grade metamorphic zone are scarce and only found in rocks with a very specific geochemical composition. In these rocks, the transitions from non-metamorphic to very low-grade (referring to the term greenschist facies of Winkler 1979) and from the very low-grade (chlorite zone of Tilley 1925) to low-grade metamorphic zone (biotite zone of Barrow 1893) take place through the diagenetic zone, the anchizone and the epizone (according to Kisch 1987), each zone being characterized by specific values of the illite Kübler Index (Kisch 1987; Árkai et al., 2003, 2007). The illite "crystallinity" (IC or Kübler-Index (referring to the pioneer study of Kübler 1964) is defined as the full width at half maximum (FWHM) of the first illite basal reflection in XRD patterns and expressed in $\Delta^{\circ} 2 \theta$ (Frey, 1987; Guggenheim et al., 2002). Guggenheim et al. (2002) recommended that the use of the term "crystallinity index" should be avoided, although it may be placed within quotation marks when referring to previously referenced work. They also recommended to refer the values to an index by citing the 
author describing the procedures to generate the index value. The proposed way of citing is much more important because the IC method is not calibrated uniformly (Kisch et al., 2004). Therefore, we will refer for $10 \AA$ FWHM values to the illite "crystallinity" for raw data and to Kübler-Index after calibration against Kübler's scale.

Illite "crystallinity" is considered to be a function of crystallite thickness, the number of lattice defects (Merriman et al., 1990) and the peak interference with discrete smectite or illite-smectite mixed layer composition (Ferreiro Mählmann et al., 2012). Temperature is thought to be the main factor controlling the illite "crystallinity", but other parameters like lithology, time, tectonic stress and fluid/rock ratio may be important (see Frey, 1987, Árkai et al., 2002). For the evolution of chlorite during diagenesis and very low-grade metamorphism, Árkai (1991) and Árkai et al. (1995) proposed the chlorite "crystallinity" (ChC) or Árkai -Index (Ál, according to Guggenheim et al., 2002) to monitor the reaction's progress.

\subsubsection{Experimental conditions}

X-ray diffraction analysis were performed using a D8-Advance Bruker-AXS (Siemens) diffractometer, Ni-filtered CuK $\alpha$ radiation at $40 \mathrm{kV}$ and $40 \mathrm{~mA}$ and primary soller slit of $2.5^{\circ}$ and divergence slit of $0.6 \mathrm{~mm}$; secondary soller slit of $2.5^{\circ}$, with detector slit of $0.1 \mathrm{~mm}$ and antiscattering slit of $0.6 \mathrm{~mm}$. Samples were crushed using an agate mortar pestle mill. Analyses of the relative content of minerals were performed with a step length of $0.02^{\circ}$ and a scan speed of $1.2^{\circ} / \mathrm{min}$ over the range $2^{\circ}-70^{\circ} 2 \theta$ for whole rocks composition.

For air-dried, ethylene glycol solvated and heated samples, measurements were performed with a step length of $0.02^{\circ}$ and a scan speed of $0.6^{\circ} / \mathrm{min}$ over the range $2^{\circ}-35^{\circ} 2 \theta$. 


\subsubsection{Illite and chlorite indices}

Seventy samples were collected in the Markstein basin (Fig. 2).

Clay mineral separation was conducted using techniques described by Schmidt et al. (1997) and following the recommendations of Kisch (1991). For the XRD analyses of $\leq 2 \mu \mathrm{m}$ fractions, textured specimen were prepared and measured, air-dried, after solvation with ethylene glycol, and after heating $\left(550^{\circ} \mathrm{C}\right)$. These three analytical steps are routinely used to better determine clay minerals content and swelling properties. Illite "crystallinity" was calculated using the software DIFFRACPlus EVAL v 12.0 (by (CBruker AXS). Illite "crystallinity" values were standardized using the "crystallinity" index-standard (CIS) samples of Warr and Rice (1994) $\left(\mathrm{KI}_{\mathrm{CIS}}=2.5734 * \mathrm{IC}_{\mathrm{IPLB}}-0.1348\right)$. The $\mathrm{IC}_{\mathrm{IPLB}}$ represents the raw data FWHM as measured at the Institut Polytechnique LaSalle Beauvais (IPLB). The Kübler-Index is used to define the limits of metamorphic zones, following the recommendations for Kübler-Index calibration of Ferreiro MähImann and Frey (2012) and the CIS-KI transformation formalism of Warr and Ferreiro Mählmann (2015). The zone boundary values were chosen as follows: $\mathrm{KI}=$ $0.25 \Delta^{\circ} 2 \theta$ for the epizone to high anchizone boundary, $\mathrm{KI}=0.30 \Delta^{\circ} 2 \theta$ for the high to low anchizone boundary and $\mathrm{KI}=0.42 \Delta^{\circ} 2 \theta$ for the low anchizone to low diagenetic zone and $\mathrm{KI}$ $=1.00 \Delta^{\circ} 2 \theta$ for the high diagenetic zone to low diagenetic zone (Table 1 ). The same experimental conditions were used to determine chlorite "crystallinity" on the 7 (002) peak of chlorite, where $(\mathrm{ChC}(002))$ corresponds to the FWHM value of the second $(7 \AA)$ basal reflection. The $\mathrm{ChC}(002)$ measurements were also standardized with the CIS sample-set of Warr and Rice (1994) and expressed as the Árkai index (Ál) according to the formulism proposed by Guggenheim et al., (2002): Ál = $1.621 * \mathrm{ChC}(002)+0.006$. The anchizone boundaries for the Árkai-Index were defined by correlation with the Kübler index at 0.30 
$\Delta^{\circ} 2 \theta$ for the epizone to anchizone boundary and $0.35 \Delta^{\circ} 2 \theta$ for the anchizone to diagenetic zone boundary.

\subsubsection{Illite polytypism and K-white mica $b$ cell dimension}

K-white mica $b$ cell dimension (or $b$ cell dimension) were determined using samples free of mixed-layered minerals and biotite. The $b$ cell dimension is based on the $d_{060,331}$ spacing and related to the increasing celadonite (Al-Si) substitution that occurs at given cation availability with pressure increase in white mica (Ernst, 1963; Guidotti et al., 1989). Guidotti et al. (1989) presented linear regression equations that quantify the changes in the $b$ cell dimension of muscovite $2 \mathrm{M}_{1}$ that result from cation substitutions in the interlayer and octahedral sites. This $b$ cell dimension value was determined by measuring the $d$ position of the $(060,331)$ peak of the potassic white mica following the procedure of Sassi and Scolari (1974). The method allows to characterize the baric type of metamorphism. The metamorphic thermal gradients are inferred from the pressure facies series of metamorphism, as follow: K-white mica $b$ cell dimension $<9.000 \AA$ correspond to low-pressure facies series (metamorphic thermal gradient $>35^{\circ} \mathrm{C} / \mathrm{km}$ ); between $9.000 \AA$ and $9.040 \AA$, a medium pressure facies series (metamorphic thermal gradient $25-35^{\circ} \mathrm{C} / \mathrm{km}$ ); and higher than $9.040 \AA$ for high-pressure facies series (metamorphic thermal gradient $<25^{\circ} \mathrm{C} / \mathrm{km}$ ). These thermal gradients correlate with hyperthermal, normal thermal and hypothermal gradients respectively determined by the correlation of KI values with vitrinite reflectance measurements (Ferreiro Mählmann et al., 2012).

Illite-muscovite polytype determination was performed using the $2 M_{1} /\left(2 M_{1}+1 M\right)$ peak ratio equation. The peak intensities were calibrated with a series of synthetic illite polytypes 
mixtures following the technique described by Dalla Torre et al. (1994). Merriman and Peacor (1999) recognized that the wealth of data on variations in white mica polytypism as a function of temperature is generally consistent with predictable trends.

\subsection{SEM-EDX}

Chemical compositions of chlorites was analyzed and used for chlorite geo-thermometric determinations. The chemical phase composition was identified with an EDX-SEM (scanning electron microscope) operating a Hitachi S3400N SEM and equipped with a Thermo Ultradry EDX probe at the Institut Polytechnique LaSalle Beauvais. A NORAN-type correction procedure was used for all data reduction and all Fe was assumed to be ferrous to simplify matters. Carbonated polished thin sections were analyzed using a $60 \mathrm{nA}$ beam current, an accelerating voltage of $15 \mathrm{kV}$, an acquisition time of $30 \mathrm{~s}$, and scanned over an area of 10 $\mathrm{mm}^{2}$.

\subsubsection{Chlorite geothermometer}

The chlorite geothermometry was carried out following the geo-thermometers established by Inoue et al. (2009) and Bourdelle et al. (2013).

The Bourdelle et al. (2013) chlorite geo-thermometer accounts applicable for all low-T chlorite compositions $\left(\mathrm{T}<350^{\circ} \mathrm{C} ; \mathrm{P}<4\right.$ kbar), but specifically for Si-rich compositions that characterizes diagenetic chlorites. To ensure the appropriate composition of chlorites the chlorite chemistry was determined with the EDX-SEM device. From these results, the cationic repartition in the structure is defined, assuming an ordered distribution on the crystal sites and thus determining the end-members ideal activities. The semi-empirical $\mathrm{T}=$ $\mathrm{f}(\log \mathrm{K})$ geothermometer is formulated as a function of $\mathrm{K}$, the equilibrium constant of the 
end-member-component reaction describing the chlorite + quartz equilibrium (function as activity).

$$
T\left({ }^{\circ} \mathrm{C}\right)=\frac{9400}{23.40-\log x}-273
$$

Where $x=\frac{\left(a_{M g-A m}^{3}\right)}{\left(a_{M g-C h l s}\right)\left(a_{M g-S u d}^{3}\right)}$

and Mg-Am: Mg-Amesite; Mg-ChIS: Mg-Chl semi-ordered; Mg-Sud: Mg-Sudoite.

The Inoue et al. (2009) geo-thermometer considers low-T disordered chlorites formed in diagenetic to very low-grade metamorphic environments. Four end-member components are used namely: Al-free trioctahedral chlorite (Afch), corundophilite ( $\mathrm{Crdp})$, chamosite (Chm) and sudoite (Sud), together with the assumption that octahedral cations and vacancies are randomly distributed in the $M$ sites. The same EDX-SEM analyses as used for the Bourdelle et al. (2013) chlorite geo-thermometer were used. From these results, the cationic repartition in the sheet silicate structure is defined, based on the hypothesis of a steady $\mathrm{Si}$ and $\mathrm{Al}$ layer order in tetrahedral sites but a random mixing in a single type of octahedral site. Then the logarithmic ideal activity is determined. The geo-thermometer is formulated as:

$$
T\left({ }^{\circ} \mathrm{C}\right)=\frac{1}{0.00264-2.897 \times 10^{-4} x}-273
$$

Where $x=\log K^{\prime}=3 \log a_{c r d p}^{i d e a l}-3 \log a_{\text {sud }}^{\text {ideal }}-\log a_{A f c h}^{\text {ideal }}$

\subsection{Vitrinite reflectance}


The chemical kinetics that governs maturation is thought to be strongly temperature dependent (e.g. Taylor et al., 1998; Polissar et al., 2011). It is known that despite vitrinite reflectance is dependent on temperature (Le Bayon et al., 2011) other optical properties of organic matter are pressure dependent, as for vitrinite see e.g. Chandra (1965) or Dalla Torre et al. (1997). The recognition of characteristic optical changes was recently used to predict different pressure conditions (Ferreiro Mählmann and Le Bayon, 2015).

Vitrinite reflectance determinations were made on a Leitz microscope (Ortholux 2 POL BK) with a $125 x$ oil-immersion objective (10x oculars) using monochromatic polarized light (546 $\mathrm{nm}$ ) and a photomultiplier MPV Leitz. In all cases, the $R_{\min }$ and $R_{\max }$ reflectance of vitrinite were determined. The photomultiplier was used to measure the reflectance intensity, which is determined through comparison with standards of known reflectance (Yttrium Aluminium Garnet single crystal, for the range of VR $=0.2$ to $2.0 \%$ ), Gallium Gadolinium Garnet single crystal (VR $=1.0$ to $3.0 \%$ ), Cubic Zirkonia ( $V R=2.0$ to $4.0 \%$ ), Diamond (VR $=4.0$ to $6.0 \%$ ), Silicium Carbide (VR $=6.0$ to $>8.0 \%)$ ).

\section{Results}

The paragenesis found in the sedimentary samples from the Markstein (MAU) and Oderen (ODU) basins are presented in Tables 2 and 3, respectively. In the Markstein samples quartz, feldspars, chlorite and illite/muscovite are the predominant phases together with the metamorphic facies indicative minerals paragonite, actinolite and biotite occurring in variable quantities. In the Oderen samples, the same main phases are detected but without the occurrence of actinolite and paragonite.

\subsection{Illite and chlorite indexes}


The Kübler-Index (KI) and Árkai-Index (Ál) were calculated from the FWHM of illite/muscovite and chlorite on the air-dry diffractogram respectively. The KI and Ál values are given in Tables 2 and 3.

In the Markstein basin $\mathrm{KI}$ values range from $1.17 \Delta^{\circ} 2 \theta$ to $0.20 \Delta^{\circ} 2 \theta$ corresponding to metamorphic grades of the diagenetic zone to epizone, respectively. The larger values are observed in the centre part of the unit, whereas at the basin border small values are measured. In contrast, in the Oderen basin, $\mathrm{KI}$ shows a narrower range of values between $0.72 \Delta^{\circ} 2 \theta$ and $0.48 \Delta^{\circ} 2 \theta$, indicative of diagenetic zone metamorphic grade. For samples containing biotite, due to the interference on the $10 \AA$-peak, KI was not determined. However, the occurrence of biotite implies epizone metamorphic conditions (Table 2). Biotite is one of the typical greenschist minerals traditionally used to distinguish the diagenesis from metamorphic conditions (Winkler, 1979), and recently used in meta-pelites to subdivide a lower greenschist facies (sub-greenschist) without biotite and greenschist facies with biotite. Because chlorite and feldspar are present in diagenetic rocks of the basins studied a reaction towards white mica + biotite $+\mathrm{SiO}_{2}+\mathrm{H}_{2} \mathrm{O}$ is envisaged. Quartz aggregations and veins are very commonly found in this metamorphic section of the basin showing that $\mathrm{SiO}_{2}$ is in excess. At the western border of the Grand Ballon intrusion in Al-rich meta-pelites also andalusite related to hornfelses is representing an inner halo of a contact metamorphism (S of Linthal, SW of the Grand Ballon). In this area, the white mica was determined by XRD as minor pyrophyllite and mainly muscovite, but chlorite is absent.

The relation between $\mathrm{KI}$ and Ál is shown in Figure 3. The correlation between the two "crystallinity" indices is only moderate $\left(R^{2}=0.39\right)$, but a general trend shows a concomitant sharpening peak evolution of both with increasing grade of metamorphism. 
The spatial distribution of samples and the metamorphic zones determined are shown in Figure 2. An area of very low-grade metamorphism (diagenesis/lower anchizone) is located in the centre of the Markstein basin surrounded by an epizonal border area. In the central part of the very low-grade area a SW to NE increase in $\mathrm{KI}$ values is obvious, thus the subzones of high-grade diagenesis, low-grade anchizone and high-grade anchizone are oriented NW/SE. To the NE, the transition to the surrounding epizone is progressive. This is in contrast with the NW and SE part of the working area. Here, the transition to the epizonal domain along the border occurs over a much shorter distance and -to the south- samples of high diagenesis grade seem to directly about the epizonal domain (Fig. 2). Biotite and actinolite are observed in samples from the epizone, and-more specifically- in all samples close to the plutons and the Klippen Belt (Fig. 2). The actinolite is restricted to samples closest located to the magmatic rocks.

\subsection{Illite polytypism and K-white mica $b$ cell dimension}

The percentages of the $2 M_{1}$ polytype determined in different samples are shown on figure 4 . A close relationship between $\% 2 \mathrm{M}_{1}$ and the $\mathrm{KI}$ can be observed. The complete conversion from $1 M_{d}$ to $2 M_{1}$ (\% of $2 M 1$ equal to 100 ) is reached at $K I$ values of the high anchizone (Fig. 5).

The K-white mica $b$ cell dimension ( $b_{0}$ in Tables 2 and 3; Fig. 6) present a spatial distribution which is linked with $\mathrm{KI}$ results. The high $\mathrm{K}$-white mica $b$ cell dimension values are located in the core of the basin, with high values of $\mathrm{KI}$ are observed. Low $b$ cell dimension values are located at the periphery of the basin, in the biotite zone with low values of KI. 


\subsection{Chlorite geothermometer}

Chlorite abundance in the analysed samples for geo-thermometry is very irregular and ranges between 3 and 51\% of the rock. The lowest chlorite contents are observed in the vicinity of the intrusions concomitant with an increase of the Illite/muscovite + biotite amount. Chemical analyses of chlorite are given in Table 4. Chlorite chemistry was normalised to 28 oxygens and fulfil the criterion $\Sigma \mathrm{Ca}+\mathrm{Na}+\mathrm{K}<0.2$ (Schmidt et al., 1997) used to test whether analyses are not contaminated by other phases. The analysed chlorites have $\mathrm{Mg} /(\mathrm{Mg}+\mathrm{Fe})$ ratios around 0.50 and Si contents below 3.00 a.p.f.u. (around 2.90 in average).

The temperatures determined with the chlorite geo-thermometer from Inoue et al. (2099) are presented in Figure 2 and Table 4. In comparison, temperatures calculated with the Inoue et al. (2009) geothermometer are 100 to $150^{\circ} \mathrm{C}$ higher than those calculated with Bourdelle et al. (2013), except for sample MAU46. Temperatures in the northern part of the Markstein basin are higher than those in the south (Oderen unit). The lowest $\mathrm{T}^{\circ} \mathrm{C}$ determined with chlorite thermometry (sample MAU 46) comes from the basin centre.

\subsection{Vitrinite reflectance}

The vitrinite reflectance data obtained for sample ODU15 (from the Oderen unit) are given in the Table 5. A second sample is from the western border of the Grand Ballon intrusion, about $1 \mathrm{~km} \mathrm{SW}$ of the peak. Different geo-thermometers exist in the literature to relate vitrinite reflectance and paleo-temperatures. Barker and Pawlewicz (1986) first proposed a relationship between $R_{0}$ and the maximum temperature recorded by the organic matter. Other geo-thermometers based on fluid inclusion calibrations in hydrothermal settings were 
also established and used here for comparison (e.g. Barker and Goldstein, 1990; Barker and Pawlewicz, 1994). A VR $-\mathrm{T}^{\circ} \mathrm{C}$ determination formulism calibrated with fluid inclusion data, but from the orogenetic setting of the Helvetic Alps was published by Mullis et al. (2002). These thermometric linear equations are time and pressure independent. It is known that VR is basically temperature dependent and time and pressure play a minor rule, depending from the geodynamic setting (see Le Bayon et al., 2011; Ferreiro Mählmann et al., 2012; Hartkopf-Fröder et al., 2015). The VR obtained in the Oderen unit, show a mean $\mathrm{R}_{\max }$ values of $6.9 \%$ and that of the Markstein unit a mean $R_{\max }$ values of $7.6 \%$. It is important to stress that the original calibration of all models used do not include high VR of the meta-anthracite and semi-graphite stage. Both measurements show a low bireflectance $\left(R_{\min } \%=2.9\right.$ and $3.15 \%$ respectively). The temperatures calculated using the different geothermometers from Barker and Pawlewiez (1986) and Barker and Goldstein (1990) are around $400^{\circ} \mathrm{C}$. Lower temperatures are estimated using the equation of Barker and Pawlewicz (1994) and Mullis et al. (2002) with values of 286 and $291^{\circ} \mathrm{C}$, respectively. Barker and Pawlewicz (1986) pointed out that their equation calculates on the maximum paleogeotherm during maturation.

\section{Discussion}

For both, the Markstein and the Oderen units, there is an apparent relation between sample location in the basin realm and metamorphic grade. Metamorphic grades are found at the basin border areas closely related to the surrounding granitic rocks.

The index minerals andalusite, biotite associated with muscovite and actinolite but also paragonite and pyrophyllite are distributed at the outer parts of the basin and close to the granites. In contrary, no index minerals are observed in the center of the basin (Fig. 2). This 
observation complements the findings of Petrini and Burg (1998), which described biotite occurrence up to $1500 m$ away from the granitic intrusion. Here, using XRD diffraction, it is possible to identify biotite in samples up to $3 \mathrm{~km}$ away from the contact due to the ability of the XRD to detect finer grained amounts. Because pyrophyllite and andalusite were observed at the intimate contact to the pluton and in granoblastic meta-sediments of hornfels character the contact metamorphic formation is best explained by metasomatism. The actinolite formation is very probable educt dependent and may show a former carbonate contend in the sedimentary rock. The reaction chlorite + feldspar $=$ white mica + black mica $+\mathrm{SiO}_{2}+\mathrm{H}_{2} \mathrm{O}$ is indicating temperatures at low pressures of $400{ }^{\circ} \mathrm{C}$, but if buffered with a Fe authigenic phase also lower temperatures of $350{ }^{\circ} \mathrm{C}$ for neo-formation is known (Brown, 1971; Bucher and Frey, 1994; Ferreiro Mählmann, 1996; Frey et al., 1999). Andalusite can also be formed at these temperatures if the educt rock is aluminous. In the pyrophyllite-bearing sample, the pyrophyllite is formed from andalusite around the crystal rims and thus probably a retrograde formation during cooling of the contact metamorphic halo.

The KI values display a similar trend in the Markstein basin, where the epizone is located at the outer parts of the basin showing increasing values to the center of the basin with diagenetic conditions occurring at the north of Markstein (Fig. 2). In the Oderen unit, the KI values of samples with or without biotite indicate a wide epizone between the Klippen Belt and a line connecting Oderen, Fellering and St. Amarin. More precision on the trends shown by $\mathrm{KI}$ and index minerals can be archived from the $\% 2 \mathrm{M}_{1}$ polytypes. Like in New Caledonia, the complete conversion of from $1 M_{d}$ to $2 M_{1}$ is reached at high anchizone (Potel et al., 2006) close to the epizone boundary (Brauckmann, 1984; Frey 1987). Maxwell and Hower (1967) shown that the complete conversion coincides or is close to the biotite isograd. The $2 \mathrm{M}_{1}$ 
values range between $32 \%$ at the north of Markstein (core of the basin) and $100 \%$ towards the border of the basin (Fig. 4).

Integration of the different parameters applied to estimate metamorphic grades demonstrates that the diagenetic to metamorphic trends along a basin transverse are well established. However, maximum temperature estimates from the different methods differ considerably: the results from Bourdelle et al. (2013) (Table 4) indicate the lowest mean temperatures between 169 and $230{ }^{\circ} \mathrm{C}$. These temperatures are typical for the high-grade diagenetic zone (Frey and Ferreiro Mählmann, 1999). The clay mineral, organic matter and mineral metamorphic indicative relationships do not prove such thermo-tectonic conditions. In comparison with all other parameters, the temperatures calculated with Bourdelle et al. (2013) under-estimate peak thermal conditions. This could be due to the chlorite composition, which have a $\mathrm{Mg} /(\mathrm{Mg}+\mathrm{Fe})$ ratio of 0.50 whereas the geo-thermometer is calibrated on Fe-rich chlorite.

Lower temperature in the low anchizone is determined in the center of the basin using the method of Inoue et al. (2009). In the range of error, the temperature estimation does not differ from the epizone of the Oderen unit (Fig. 2). The anchizone is mostly related to temperatures of $230 \pm 20{ }^{\circ} \mathrm{C}$ and $320 \pm 30^{\circ} \mathrm{C}$ in orogenic settings and most sedimentary basins and documented in generalized relationships with the same clay mineral indices used in the present study (Sròdon, 1984; Weaver, 1989; Schiffman and Friedleifsson, 1991; Merriman and Frey, 1999). Referring to the same literature (e.g. Merriman and Frey, 1999; Potel et al., 2006), minimum temperature admitted for epizonal conditions is around $300^{\circ} \mathrm{C}$; thus temperatures calculated using the Inoue et al. (2009) geo-thermometer are significantly but still too low (mean $265{ }^{\circ} \mathrm{C}$ in the biotite free epizone). If the values from the biotite-in 
index boundary (Barrow, 1887) are compared with the possible existence of a biotite-in isograde (Winkler, 1979) also mean-temperature estimates of 294 to $331^{\circ} \mathrm{C}$ are 20 to $100{ }^{\circ} \mathrm{C}$ to low. These temperatures are coherent with the $288+/-11^{\circ} \mathrm{C}$ calculated on the VR sample using the two geo-thermometers of Barker and Pawlewicz (1994) and Mullis et al. (2001) (Table 5). But the sample is from the southernmost part of the study area and metamorphic conditions not well constrained with the other methods. The temperatures calculated by the equation from Barker and Pawlewicz (1986) and Barker and Goldstein (1990) are closer to $400^{\circ} \mathrm{C}$ as is expected due to the possible existence of a biotite-in isograde. Concluding from previous publications of Barker and Pawlewicz (1994) they differenced, postulating an equation for normal burial conditions and one for hydrothermal conditions. Thus a peak temperature of 300 or $400{ }^{\circ} \mathrm{C}$ must be discussed according to the geodynamic setting, still to be proposed for the Markstein basin. "One strength of this approach is the simple calculation of maximum paleotemperatures, one weakness is that just two heating rates are considered rather than a wide spectrum of heating rates in nature" (Hartkopf-Fröder et al., 2015). Also the geo-thermometer of Mullis et al. (2002), at least calibrated in the Helvetic Alps, may be applied preferentially for barrovian thermal conditions (Ferreiro Mählmann et al., 2012, with an extensive critical review). On the other hand, using the temperaturepressure-time (T-P-t) equation of Dalla Torre et al. (1997) some information about the heating period is needed in order to judge if temperatures of 400 or $650^{\circ} \mathrm{C}$ are in accordance with the thermal history in the inner halo of contact metamorphism.

Figure 6 shows gravimetric results (Skrzypek et al., 2012) in relation with KI values, biotite occurrence and K-white mica $b$ cell dimension. The low density zones seem to be related to granitic intrusions, which appear also to underlie the northernmost Oderen unit along the Klippen Belt. Higher densities are observed north of Markstein in the core of the basin, and 
have been related to increasing basin thickness (Skrzypek et al., 2012). This latter area corresponds also to high $\mathrm{KI}$ values (diagenetic zone to anchizone) with K-white mica $b$ cell dimension values greater than $9.000 \AA$ (up to $9.027 \AA ̊$ ). Distribution of KI values indicate that epizonal conditions are closely related to zones of low density, and hence the distribution of granites. In these areas, the K-white $b$ cell dimension values are close to or below $9.000 \AA$. The close relationship between clay mineral indices, Bouguer anomalies and intrusion contacts unequivocally demonstrate the thermal control of the epizone by magmatic heating.

The K-white mica $b$ cell dimension values close to or below $9.000 \AA$ are indicative of a lowpressure metamorphic facies (Sassi, 1972; Sassi and Scolari, 1974), which we interpret to be related to the contact metamorphism induced by the intrusion of the granitic rocks surrounding and partly underlying the basin. Assuming that a) the heating time at peak conditions was $5 \mathrm{Ma}$ (time of the intrusion interval), and b) the pressure gradient was characteristic for a hyperthermal gradient the T-P-t model of Dalla Torre et al. (1997) is reconsidered and a temperature of 600 to $650{ }^{\circ} \mathrm{C}$ at 1.0 to $4.0 \mathrm{kbar}$ at the pluton contact is calculated (this is consistent with temperatures of 650 to $700{ }^{\circ} \mathrm{C}$ given for a granite melt at high $\mathrm{aH}_{2} \mathrm{O}$, Bucher and Frey, 1994). Similar VR-T ${ }^{\circ} \mathrm{C}$ relationships were calibrated and modeled at the Vichuquén basin intrusions (Belmar et al., 2002) and at the Val Fredda Quartzdiorite (Ferreiro MähImann et al., 2012). The KI-VR relationship found at the SW of the Grand Ballon showing anchizone/epizone boundary KI-values and high meta-anthracite VR-values of 6.9 and $7.6 \mathrm{R}_{\max } \%$ are plotted into the KI-VR thermal gradient diagram of Ferreiro Mählmann et al. (2012) indicative for hyperthermal heat flow conditions or contact metamorphism. 
The higher values of K-white mica $b$ cell dimension in the centre of the basin are better in accordance with a burial or orogenic metamorphism of medium pressure type. A VR study is missing in this part and a more detailed interpretation remains speculative.

\section{Conclusion}

The metamorphic evolution of the Markstein basin can be reconstructed with a multimethod approach involving metamorphic mineral assemblage formation, K-white mica evolution, vitrinite maturity and chemical. The study allowed to decipher the range of different thermal events on the very low-grade to low-grade metamorphic pattern offering a powerful tool to reconstruct the thermal evolution of the basin. The K-white mica $b$ cell dimension indicate the limit of the contact metamorphism effects to be more far reaching into the basin than shown by index minerals like biotite or actinolite. In this context it seems rather surprisingthat the Markstein basin center, despite being surrounded by large plutons, still preserved burial or orogenic normal-thermal diagenetic to anchizone metamorphic rocks.

Comparing the methods to determine maximum temperatures it is likely that the chloritethermometers differ in their thermal significance. It must be demonstrated if the chlorite chemistry is appropriate to be applied for a particular thermometer.In case of the VR methods used much more data are needed and more information about the geodynamic evolution. In case of the Markstein basin it is difficult to fix the modeling parameters. Nevertheless, the thermometry used calibrated on burial and normal orogenic conditions most probably define much better the very low-grade and diagenetic zone temperatures. In case of the epizone contact metamorphism the hydrothermal calibrated methodology is 
preferred. Also knowing that intrusion time lasted for $5 \mathrm{Ma}$ using the VR-T-P-t model the upper range of temperature of close to $650^{\circ} \mathrm{C}$ at the inner contact halo, $400{ }^{\circ} \mathrm{C}$ at the biotite in zone boundary and $>320^{\circ} \mathrm{C}$ at the anchizone to epizone limit seem to be very realistic.

\section{Acknowledgements}

\section{References}

Árkai, P., 1991. Chlorite crystallinity: an empirical approach and correlation with illite crystallinity, coal rank and mineral facies as exemplified by Palaeozoic and Mesozoic rocks of northeast Hungary. J. of metam. Geol. 9, 723-734.

Árkai, P., Sassi, F.P., Sassi, R., 1995. Simultaneous measurements of chlorite and illite crystallinity: a more reliable tool for monitoring low- to very low grade metamorphisms in metapelites. A case study from the Southern Alps (NE Italy). Eur. J. Mineral. 7,1115-1128.

Árkai, P., Ferreiro Mählmann, R., Suchy, V., Balogh, K., Sýkorová, I., Frey, M., 2002. Possible effects of tectonic shear strain on phyllosilicates: a case study from the Kandersteg area, Helvetic domain, Central Alps, Switzerland. Schweiz. Mineral. Petrogr. Mitt. 82, 273-290.

Árkai, P., Faryad, S.W., Vidal, O., Balogh, K., 2003. Very low-grade metamorphism of sedimentary rocks of the Meliata unit, Western Carpathians, Slovakia: implications of phyllosilicate characteristics. Int. J. Earth Sci.92, 68-85. 
Árkai, P., Sassi, F.P., Desmons, J., 2007. Very low- to low-grade metamorphic rocks In: D Fettes, J Desmons (eds): Metamorphic Rocks: A Classification and Glossary of Terms: Recommendations of the International Union of Geological Sciences Subcommission on the Systematics of Metamorphic Rocks. Cambridge University Press, Cambridge, UK, pp 36-42.

Barker, C.E., Goldstein, R.H., 1990. Fluid-inclusion technique for determining maximum temperature in calcite and its comparison to the vitrinite reflectance geothermometers. Geology 18, 1003-1006.

Barker, C.E., Pawlewicz, M.J., 1986. The correlation of vitrinite reflectance with maximum temperature in humic organic matter. Lect. Notes Earth Sci. 5, 79-81.

Barker, C.E., Pawlewicz, M.J., 1994. Calculation of vitrinite reflectance from thermal histories and peak temperatures. A comparison of methods. In: Mukhopadhyay, P.K., Dow, W.G. (Eds.), Vitrinite Reflectance as a Maturity Parameter: Applications and Limitations. ACS Symp Series 570, 216-229.

Barrow G., 1893. On an intrusion of muscovite-biotite gneiss in the south-eastern Highlands of Scotland and it accompanying metamorphism. J. Geol. Soc. London 49, 330-358.

Belmar, M., Schmidt, S Th, Ferreiro Maählmann, R., Mullis, J., Stern, W. B., Frey, M., 2002. Diagenesis, low-grade and contact metamorphism in the Triassic-Jurassic of the VichuquenTilicura and Hualace'n Gualleco basins, Coastal Range of Chile. In: S.Th. Schmidt \& R. Ferreiro Mählmann (Eds.) Diagenesis and low grade metamorphism. Schweiz. Mineral. Petrogr. Mitt. $82,375-392$.

Bourdelle, F., Parra, T., Chopin, C., Beyssac, O., 2013. A new chlorite geothermometers for diagenetic to low-grade metamorphic conditions. Contrib. Mineral. Petr. 165, 723-735. 
Brauckmann, F.J., 1984. Hochdiagenese im Muschelkalk der Massive von Bramsche und Vlotho. Bochumer Geologische und Geotechnische Arbeiten 14, 1-195.

Bucher K., Frey M., 1994. Petrogenesis of metamorphic rocks. Berlin ; New York : SpringerVerlag, c1994. $318 \mathrm{p}$.

Chandra, D., 1965. Reflectance of coals carbonized under pressure. Econ. Geol. 60, 621-629.

Dalla Torre, M., Stern, W. B., Frey, M., 1994. Determination of white K-mica polytype ratios: comparison of different XRD methods. Clay Miner.29, 717-726.

Dalla Torre, M., de Capitani, C., Frey, M., Underwood, M. B., Mullis, J., Cox, C., 1996. Verylow temperature metamorphism of shales from the Diablo Range, Franciscan complex, California: new constraints on the exhumation path. Geol. Soc. Am. Bull.108, 578-601.

Dalla Torre M., Ferreiro Mählmann R., Ernst W.G., 1997. Experimental study on the pressure dependence of vitrinite maturation. Geochim. Cosmochim. Ac. 61, 2921-2928.

Edel J.B., Fluck, P., 1989. The upper Rhenish Shield basement (Vosges, Upper Rhinegraben and Schwarzwald): Main structural features deduced from magnetic, gravimetric and geological data. Tectonophysics 169, 303-316.

Ernst, W. G., 1963. Significance of phengitic micas from low grade schists. Am. Mineral. 48, 1357-1373.

Ferreiro Mählmann R., 1996. The pattern of diagenesis andmetamorphism by vitrinite reflectance and illite-cristallinity in Mittelbunden and in the Oberhalbstein. 2. Correlation of coal petrography and of mineralogical parameters. Schweiz. Mineral. Petrogr. Mitt. 76, 2346. 
Ferreiro Mählmann, R., Frey, M., 2012. Standardisation, calibration and correlation of the Kübler-Index and the vitrinite/bituminite reflectance: an inter-laboratory and field related study. In: Ferreiro Mählmann, R., Bozkaya, Ö., Potel, S., Nieto, F. (Eds.), Swiss Journal of Geosciences 105, 153-170.

Ferreiro Mählmann R., Le Bayon, R., 2015. Vitrinite and vitrinite like solid bitumen reflectance in thermal maturity studies: correlations from diagenesis to incipient metamorphism in different geodynamic settings. Int. J. Coal Geol. http://dx.doi.org/10.1016/j.coal.2015.12.008

Ferreiro Mählmann, R., Botzkaya, O., Potel, S., Le Bayon, R., Šegvić, B., Nieto García, F., 2012. The pioneer work of Bernard Kübler and Martin Frey in very low-grade metamorphic terranes: paleo-geothermal potential of variation in Kübler-Index/organic matter reflectance correlations. A review. Swiss Journal of Geosciences 105,121-152.

Franke, W., 2000. The mid-European segment of the Variscides: tectonostratigraphic units, terrane boundaries and plate tectonic evolution. In: Franke W, Haak V, Oncken O, Tanner D (eds) Orogenic processes: quantification and modelling in the Variscan belt, vol 179. Geological Society Special Publications, London, pp 35-62

Frey, M., 1969. Die Metamorphose des Keupers vom Tafeljura bis zum Lukmanier-Gebiet (Veränderungen tonig-mergeliger Gesteine vom Bereich der Diagenese bis zur StaurolithZone). Beiträge zur geologischen Karte der Schweiz, 137, Bern.

Frey, M., 1987. Low temperature metamorphism. Glasgow and London: Blackie.

Frey, M., Ferreiro Mählmann, R., 1999. Alpine metamorphism of the Central Alps. Schweiz. Mineral. Petrogr. Mitt. 79, 135-154. 
Frey, M., Robinson, D., 1999. Low-grade metamorphism. Oxford: Blackwell Science.

Frey, M., Desmons, J., Neubauer, F.,1999. Alpine Metamorphic Map 1:500 000. Schweiz. Mineral. Petrogr. Mitt. 79, 1-4.

Gagny, C., 1962. Caractères sédimentologiques et pétrographiques des schistes et grauwackes du culm dans les Vosges méridionales. Bulletin du Service de la Carte Géologique d'Alsace-Lorraine, 15, p.139-160.

Gagny, C., 1968. Pétrogenèse du granite des crêtes (Vosges méridionales, France). Mémoire: Nantes $546 p$.

Gagny, C., Jung, J., Huu Nghiep, H., Mattauer, M., Théobald, N., Tricart, J., Cloots, A., Flageollet, J.C., Zinglé, J.B., Ménillet, F., Shumacher, M.F., Ruhland, M., Lillié, F., Fluck, P., 1976. Munster. 1/50 000. BRGM.

Guggenheim, S., Bain, D.C., Bergaya, F., Brigatti, M.F., Drits, V., Eberl, D.D., Formoso, M., Gala'n, E., Merriman, R.J., Peacor, D.R., Stanjek, H., Watanabe, T., 2002. Report of the AIPEA nomenclature committee for 2001: order, disorder and crystallinity in phyllosilicates and the use of the "Crystallinity Index". Clay Minerals, 37, 389-393.

Guidotti, C. V., Sassi, F. P., Blencoe, J. G., 1989. Compositional controls on the a and b cell dimensions of $2 \mathrm{M}_{1}$ Muscovites. Eur. J. Mineral. 1, 71-84.

Hammel, C., 1996. Une faune nouvelle de trilobites (Brachymetopus, Namuropyge) dans le Viséen des Vosges du Sud. Conséquences stratigraphiques et paléoécologiques. Géobios 29, 745-755. 
Hartkopf-Fröder, C., Königshof, P., Littke, R., Schwarzbauer, J. (2015). Optical thermal maturity parameters and orgnaic geochemical alteration at low grade diagenesis to anchimetamorphism: A review. Int. J. Coal Geol. http://dx.doi.org/10.1016/j.coal.2015.06.005

Inoue, A., Meunier, A., Patrier-Mas, P., Rigault, C., Beaufort, D., Vieillard, P., 2009. Application of chemical geothermometry to low-temperature trioctahedral chlorites. Clay Clay Miner. 57, 371-382.

Jung, J., 1928. Contribution à la géologie des Vosges hercyniennes d'Alsace. Mémoire : Université de Strasbourg. 480 p.

Kalt, A., Hanel, M., Schleicher, H., Kramm, U., 1994. Petrology and geochronology of eclogites from the Variscan Schwarzwald (F.R.G.). Contrib. Mineral. Petr. 115, 287-302.

Kalt, A., Altherr, R., 1996. Metamorphic evolution of garnet-spinel peridotites from the Variscan Schwarzwald (Germany). Geol. Rundsch. 85, 211-224.

Kisch, H.J., 1987. Correlation between indicators of very low grade metamorphism. In: Frey, M. (Ed.), Low Temperature Metamorphism. Blackie, Glasgow \& London, pp. 227-300.

Kisch, H.J., 1991. Illite crystallinity: recommendation on sample preparation, X-Ray diffraction settings, and interlaboratory samples. J. of metam. Geol. 9, 665-670.

Kisch, H.J., Árkai, P., Brime, C., 2004. On the calibration of the illite Kübler index (illite „crystallinity”). Schweiz. Mineral. Petrogr. Mitt. 84, 323-331.

Kossmat, F., 1927. Gliederung der varistischen Gebirgsbaues. Abhandlungen des Sächsischen Geologischen Landesamts 1, 1-39. 
Krecher, M., 2005. Die Turbiditsandstein-Komplex der devono-karbonischen Markstein Gruppe im Oberelsass (NE-Frankreich) und ihre Beziehungen zu den moldanubischen Gesteinseinheiten von Schwarzwald und Vogesen. Dissertation zur Erlangung des Doktorgrades: Albert-Ludwigs-Universität Freiburg i.Br. 308 p.

Krecher, M., Grimm, B., Müller-Sigmund, H., Behrmann, J.-H., 2007. Sedimentology and tectonic setting of Devonian-Carboniferous turbidites and debris flow deposits in the Variscan Vosges Mountains (Markstein Group, NE-France). Zeitschrift der Deutschen Geologischen Gesellschaft 158, 1063-1087.

Kretz, R., 1983. Symbols for rock-forming minerals. Am. Mineral. 68, 277-279.

Krumm, H., 1984. Anchimetamorphose im Anis und Ladin (Trias) der Nördlichen Kalkalpen zwischen Arlberg und Kaisergebirge-ihre Verbeitung und deren baugeschichtliche Bedeutung. Geol. Rundsch. 73, 223-257.

Kübler, B., 1964. Les argiles, indicateurs de métamorphisme. Revue de l'Institut Français du Pétrole 19, 1093-1112.

Kübler, B., 1967. La cristallinité de l'illite et les zones tout à fait supérieures du métamorphisme. Etages tectoniques. Colloques Neuchâtel, 18-21 avril 1967, 105-122.

Kübler, B., 1968. Evaluation quantitative du métamorphisme par la cristallinité de l'illite. Bulletin Centre Recherche Pau, S.N.P.A., 2, 385-397.

Le Bayon, R., Brey, G.P., Ernst, W.G., Ferreiro Mählmann, R. , 2011. Experimental kinetic study of organic matter maturation: Time and pressure effects on vitrinite reflectance at $400{ }^{\circ} \mathrm{C}$. Org. Geochem. 42, 340-355. 
Maas, R., 1988. Die Südvogesen in variszischer Zeit. Neues Jahrbuch für Geologie und Paläontologie. Monatshefte, 10, 611-638.

Maxwell, D. T., Hower, J., 1967. High-grade diagenesis and low-grade metamorphism of illite in the Precambrian Belt Series: Am. Mineral. 52, 843-856.

Merriman, R.J., Roberts, B., Peacor, D.R., 1990. A transmission electron microscope study of white mica crystallite size distribution in a mudstone to slate transitional sequence, North Wales, UK. Contrib Mineral Petrol 106, 27-40.

Merriman, R. J., Frey, M., 1999. Patterns of very low-grade metamorphism in metapelitic rocks. In M. Frey \& D. Robinson (Eds.), Low-grade metamorphism (pp. 61-107). Oxford: Blackwell Science.

Merriman, R. J., Peacor, D. R., 1999. Very low-grade metapelites: mineralogy, microfabrics and measuring reaction progress. In M. Frey \& D. Robinson (Eds.), Low-grade metamorphism (pp. 10-60). Oxford: Blackwell Science.

Mullis, J., Rahn, K. M., Schwer, P., Capitani, C., Stern, W. B., Frey M., 2002. Correlation of fluid inclusion temperatures with illite "crystallinity" data and clay mineral chemistry in sedimentary rocks from the external part of the Central Alps. Schweiz. Mineral. Petrogr. Mitt. 82, 325-340.

Petrini, K., Burg, J.-P., 1998. Relationship between deformation, plutonism and regional metamorphism in the Markstein area (southern Vosges). Geologie de la France 2, 13-23.

Polissar, P.J., Savage, H.M., Brodsky, E.E., 2011. Extractable organic material in fault zones as a tool to investigate frictional stress: Earth Planet. Sc. Lett. 311, 439-447. 
Potel, S., Ferreiro Mählmann, R., Stern, W. B., Mullis, J., Frey, M., 2006. Very low-grade metamorphic evolution of pelitic rocks under high-pressure/low-temperature conditions, NW New Caledonia (SW Pacific). J. Petrol. 47, 991-1015.

Price and Wenger (1992);

Sassi, F. P., 1972. The tetrological and geological significance of the $b_{0}$ values of potassic white micas in low-grade metamorphic rocks. An application to the Eastern Alps. Tscher. Miner. Petrog. 18, 105-113.

Sassi, F. P., Scolari, A., 1974. The $b_{0}$ of the potassic white micas as a barometric indicator in low-grade metamorphism of pelitic schists. Contrib. Min. Petrol. 45, 143-152.

Schaltegger, U., Schneider, J.-L., Maurin, J.-C., Corfu, F., 1996. Precise U-Pb chronometry of 345-340 Ma old magmatism related to syn-convergence extension in the Southern Vosges (Central Variscan Belt). Earth Planet. Sc. Lett. 144, 403-419

Schiffman, P., Fridleifsson, G.O., 1991. The smectite-chlorite transition in drill-hole NJ-15, Nesjavellir geothermal field, Iceland: XRD, BSE and electron microprobe investigations. J. of metam. Geol. 9, 679-696.

Schmidt, D., Schmidt, S. Th., Mullis, J., 1997. Very low grade metamorphism of the Taveyanne formation of western switzerland. Contrib. Min. and Petrol. 129, 385-403.

Schneider, J.-L., 1990. Enregistrement de la dynamique varisque dans les bassins volcanosédimentaires dévono-dinantiens: exemple des Vosges du Sud. Thèse de doctorat: Université de Strasbourg. 222 p. 
Skrzypek, E., Tabaud, A.-S., Edel, J.-B., Schulmann, K., Cocherie, A., Guerrot, C., Rossi, P., 2012. The significance of Late Devonian ophiolites in the Variscan orogen: a record from the Vosges Klippen Belt. Int. J. Earth Sci.101, 951-972.

Środoń J., 1984. X-ray powder diffraction identification of illitic materials. Clay Clay Miner. $32,337-349$.

Stach, E., Mackowsky, M.Th., Teichmüller R, M., Taylor, G.H., Chandra, D., Teichmüller, R., 1982. Textbook of Coal Petrology, p538. 3rd. edns. Stuttgart: Bornträger.

Tabaud, A.-S., Whitechurch, H., Rossi, P., Schulmann, K., Guerrot, C. \& Cocherie, A., 2014. DevonianPermian magmatic pulses in the northern Vosges Mountains (NE France): result of continuous subduction of the Rhenohercynian Ocean and Avalonian passive margin. In: Schulmann, K., Martı́nez Catala'n, J. R., Lardeaux, J. M., Janous`ek, V. \& Oggiano, G. (eds) The Variscan Orogeny: Extent, Timescale and the Formation of the European Crust. Geological Society, London, Special Publications, 405. First published online April 1, 2014, http://dx. doi.org/10.1144/SP405.12

Taylor, G.H., Teichmüller, M., Davies, A., Diessel, C.F.K., Littke, R., Robert, P., 1998. Organic Petrology. Gebrüder Borntraeger, Berlin (704 pp.)

Tilley, C.E., 1925. Metamorphic zones in the southern Highlands of Scotland. J. Geol. Soc. London 81, $100-112$.

Turner, F.J., 1968. Metamorphic petrology: Mineralogical and field aspects. New York: McGraw-Hill.

Warr, L. N., Rice, A. H., 1994. Interlaboratory standardization and calibration of clay mineral crystallinity and crystallite size data. J. of metam. Geol. 12, 141-152. 
Warr, L. N., Ferreiro Mählmann, R., 2015. Recommendations for Kübler Index standardization. Clay Miner. 50, 282-285.

Weaver, C. E., 1961. Clay Miner.of the Ouachita structural belt and adjacent foreland: Univ. Texas, Bur. Economics, Geology Publications 6120, 147-162.

Weaver, C.E., 1989. Clays, Muds and Shales. Developments in Sedimentology (vol. 44). Amsterdam: Elsevier.

Winkler, H. G. F., 1979. Petrogenesis of metamorphic rocks ( $5^{\text {th }}$ ed.). Berlin: Springer. 


\section{Figure captions}

Figure 1: Structural map of the Vosges showing the major tectonic units, after Tabaud et al. (2014). Onset showing the Variscan belt and the localization of the Vosges, modified after Franke (2000).

Figure 2: Distribution of Kübler Index (KI) values in the study area. Distribution of K-white micas $b$ cell dimension and minerals index (Bt: biotite; Act: actinolite). Temperatures calculated by Inoue et al. (2009) geothermometer and temperature calculated for vitrinite reflectance sample (average from Barker and Pawlewicz (1994) and Mullis et al. (2002)) are also represented. Lithological map modified after Skrzypek et al. (2012).

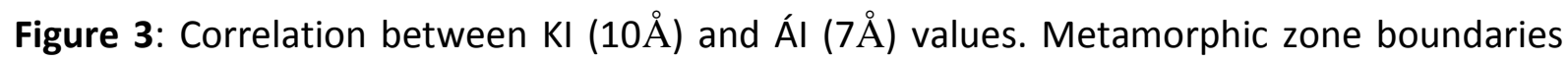
are after Warr and Ferreiro Mählmann (2015).

Figure 4: Distribution of Kübler Index (KI) values and of $\% 2 \mathrm{M}_{1}$ polytypes in the study area. Lithological map modified after Skrzypek et al. (2012).

Figure 5: Distribution pattern of $\% 2 \mathrm{M}_{1} \mathrm{~K}$-white mica content of samples in the Markstein Basin.

Figure 6: Distribution of Kübler Index (KI) values, K-white micas $b$ cell dimension and minerals index (Bt: biotite; Act: actinolite). The Bouguer anamaly map of the southern Vosges is after Skrzypek et al. (2012). Lithological map modified after Skrzypek et al. (2012).

Table 1: Metamorphic zone boundaries for Kübler Index (KI) and Árkai Index (Ál) values after Warr and Ferreiro Mählmann (2015). 
Table 2: Paragenese of studied samples in the Markstein Unit (MAU), FWHM (full width at half maximum intensity) of the (001) illite/muscovite reflection and (002) chlorite reflection and their values after calibration in $\mathrm{KI}$ and Ál, respectively. K-white mica $b$ cell dimension and \%2M1 illite/muscovite polytypes is given for samples where it was possible to determined them. n.d., not determined. Minerals abbreviations are from Kretz (1983).

Table 3: Paragenese of studied samples in the Oderen Unit (ODU), FWHM (full width at half maximum intensity) of the (001) illite/muscovite reflection and (002) chlorite reflection and their values after calibration in $\mathrm{KI}$ and Ál, respectively. K-white mica $b$ cell dimension and \%2M1 illite/muscovite polytypes is given for samples where it was possible to determined them. n.d., not determined. Minerals abbreviations are from Kretz (1983).

Table 4: Representative chemical analyses of chlorite based on 14 oxygens. Calculations are based on 14 oxygens (anhydrous basis). SD: standard deviation. Temperature are calculated using the geothermometer from Inoue et al. (2009) and Bourdelle et al. (2013).

Table 5: Vitrinite reflectance data for sample ODU15. Temperature are calculated from different geothermometers: (1) Barker and Pawlewicz (1986), (2) Barker and Goldstein (1990), (3) Barker and Pawlewicz (1994), (4) Mullis et al. (2002). 
Table 1

\begin{tabular}{|c|c|c|}
\hline Metamorphic grade & KI & Ál \\
\hline Diagenesis & \multirow{2}{*}{0.42} & \multirow{2}{*}{0.35} \\
\hline Lower Anchizone & & \\
\hline Upper Anchizone & 0.30 & \\
\hline Epizone & 0.25 & 0.30 \\
\hline
\end{tabular}


Table 2

\begin{tabular}{|c|c|c|c|c|c|c|c|c|c|c|c|c|c|}
\hline & & \multicolumn{6}{|c|}{ Parageneses } & \multicolumn{2}{|c|}{ Illite/Muscovite } & \multicolumn{2}{|c|}{ Chlorite } & \multirow[b]{2}{*}{$b_{0}$} & \multirow[b]{2}{*}{$\% 2 \mathrm{M} 1$} \\
\hline Sample & Qtz & Fsp & $\mathrm{Chl}$ & Ill/Mus & Act & $\mathrm{Bt}$ & $\mathrm{Pg}$ & FWHM001 & $\mathrm{KI}$ & FWHM002 & $\mathrm{AI}$ & & \\
\hline MAU01 & $38 \%$ & $21 \%$ & $17 \%$ & $23 \%$ & & & & 0.261 & 0.38 & 0.199 & 0.33 & 9.008 & 58 \\
\hline MAU02 & $42 \%$ & $24 \%$ & $14 \%$ & $20 \%$ & & & & 0.456 & 0.69 & 0.259 & 0.43 & 9.025 & 78 \\
\hline MAU03 & $24 \%$ & $23 \%$ & $28 \%$ & $25 \%$ & & & & 0.290 & 0.43 & 0.217 & 0.36 & & \\
\hline MAU04 & $43 \%$ & $18 \%$ & $18 \%$ & $22 \%$ & & & & 0.265 & 0.39 & 0.272 & 0.45 & & \\
\hline MAU05 & $38 \%$ & $26 \%$ & $10 \%$ & $26 \%$ & & & & 0.371 & 0.56 & 0.260 & 0.43 & 9.027 & 32 \\
\hline MAU06 & $27 \%$ & $44 \%$ & $3 \%$ & $9 \%$ & $10 \%$ & $8 \%$ & & 0.305 & n.d. & 0.197 & 0.33 & & \\
\hline MAU07 & $38 \%$ & $21 \%$ & $11 \%$ & $18 \%$ & & $11 \%$ & & 0.343 & n.d. & 0.175 & 0.29 & & \\
\hline MAU08 & $30 \%$ & $30 \%$ & $9 \%$ & $26 \%$ & & $5 \%$ & & 0.365 & n.d. & 0.255 & 0.42 & 8.980 & \\
\hline MAU09 & $31 \%$ & $19 \%$ & $20 \%$ & $26 \%$ & & $5 \%$ & & 0.372 & n.d. & 0.235 & 0.39 & & \\
\hline MAU10 & $20 \%$ & $22 \%$ & $39 \%$ & $19 \%$ & & & & 0.643 & 1.00 & 0.223 & 0.37 & & \\
\hline MAU11 & $12 \%$ & $28 \%$ & $14 \%$ & $17 \%$ & $29 \%$ & & & 0.162 & 0.22 & 0.251 & 0.41 & & \\
\hline MAU12 & $27 \%$ & $14 \%$ & $35 \%$ & $23 \%$ & & & & 0.212 & 0.30 & 0.163 & 0.27 & & \\
\hline MAU13 & $41 \%$ & $19 \%$ & $15 \%$ & $24 \%$ & & & & 0.237 & 0.34 & 0.192 & 0.32 & 8.990 & 50 \\
\hline MAU14 & $29 \%$ & $23 \%$ & $26 \%$ & $22 \%$ & & & & 0.221 & 0.31 & 0.179 & 0.30 & 9.007 & 55 \\
\hline MAU15 & $47 \%$ & $19 \%$ & $15 \%$ & $20 \%$ & & & & 0.164 & 0.22 & 0.227 & 0.37 & 8.967 & 100 \\
\hline MAU16 & $32 \%$ & $19 \%$ & $21 \%$ & $24 \%$ & & $4 \%$ & & 0.173 & n.d. & 0.141 & 0.23 & & \\
\hline MAU17 & $32 \%$ & $23 \%$ & $14 \%$ & $20 \%$ & & $11 \%$ & & 0.279 & n.d. & 0.178 & 0.29 & & \\
\hline MAU18 & $25 \%$ & $21 \%$ & $28 \%$ & $26 \%$ & & & & 0.209 & 0.30 & 0.203 & 0.33 & 9.009 & 100 \\
\hline MAU20 & $35 \%$ & $33 \%$ & $5 \%$ & $17 \%$ & & $10 \%$ & & 0.316 & n.d. & 0.181 & 0.30 & & \\
\hline MAU21 & $37 \%$ & $20 \%$ & $21 \%$ & $22 \%$ & & & & 0.171 & 0.23 & 0.155 & 0.26 & 9.004 & 91 \\
\hline MAU22 & $34 \%$ & $18 \%$ & $24 \%$ & $24 \%$ & & & & 0.281 & 0.47 & 0.216 & 0.36 & 9.010 & 54 \\
\hline MAU23 & $32 \%$ & $17 \%$ & $23 \%$ & $23 \%$ & & $5 \%$ & & 0.460 & n.d. & 0.282 & 0.46 & & \\
\hline MAU24 & $29 \%$ & $17 \%$ & $33 \%$ & $21 \%$ & & & & 0.217 & 0.33 & 0.175 & 0.29 & 9.001 & 100 \\
\hline MAU25 & $45 \%$ & $16 \%$ & $6 \%$ & $16 \%$ & & $17 \%$ & & 0.347 & n.d. & 0.234 & 0.39 & & \\
\hline MAU26 & $19 \%$ & $14 \%$ & $51 \%$ & $13 \%$ & & $3 \%$ & & 0.377 & n.d. & 0.180 & 0.30 & & \\
\hline MAU27 & $26 \%$ & $17 \%$ & $22 \%$ & $17 \%$ & & $19 \%$ & & 0.325 & n.d. & 0.225 & 0.37 & & \\
\hline MAU28 & $28 \%$ & $31 \%$ & $17 \%$ & $20 \%$ & & $4 \%$ & & 0.459 & n.d. & 0.181 & 0.30 & 9.000 & \\
\hline MAU29 & $36 \%$ & $22 \%$ & $14 \%$ & $22 \%$ & & $5 \%$ & & 0.317 & n.d. & 0.226 & 0.37 & & \\
\hline MAU30 & $39 \%$ & $20 \%$ & $16 \%$ & $26 \%$ & & & & 0.594 & 1.17 & 0.265 & 0.44 & & \\
\hline MAU31 & $10 \%$ & $31 \%$ & $9 \%$ & $31 \%$ & $11 \%$ & $8 \%$ & & 0.285 & n.d. & 0.215 & 0.35 & & \\
\hline MAU32 & $26 \%$ & $24 \%$ & $6 \%$ & $18 \%$ & & $27 \%$ & & 0.274 & n.d. & 0.251 & 0.41 & & \\
\hline MAU33 & $25 \%$ & $24 \%$ & $15 \%$ & $19 \%$ & & $6 \%$ & $11 \%$ & 0.420 & n.d. & 0.209 & 0.34 & & \\
\hline MAU34 & $9 \%$ & $41 \%$ & $11 \%$ & $23 \%$ & $12 \%$ & $5 \%$ & & 0.278 & n.d. & 0.232 & 0.38 & & \\
\hline MAU35 & $20 \%$ & $45 \%$ & $12 \%$ & $23 \%$ & & & & 0.214 & 0.32 & 0.177 & 0.29 & & \\
\hline MAU36 & $29 \%$ & $24 \%$ & $26 \%$ & $21 \%$ & & & & 0.182 & 0.25 & 0.138 & 0.23 & & \\
\hline MAU37 & $33 \%$ & $25 \%$ & $19 \%$ & $23 \%$ & & & & 0.194 & 0.28 & 0.144 & 0.24 & & \\
\hline MAU38 & $42 \%$ & $30 \%$ & $12 \%$ & $16 \%$ & & & & 0.458 & 0.87 & 0.190 & 0.31 & & \\
\hline MAU39 & $44 \%$ & $21 \%$ & $5 \%$ & $21 \%$ & & $9 \%$ & & 0.291 & n.d. & 0.181 & 0.30 & & \\
\hline MAU40 & $40 \%$ & $20 \%$ & $16 \%$ & $19 \%$ & & $5 \%$ & & 0.288 & n.d. & 0.274 & 0.45 & & \\
\hline MAU41 & $39 \%$ & $20 \%$ & $12 \%$ & $29 \%$ & & & & 0.164 & 0.21 & 0.162 & 0.27 & & \\
\hline MAU42 & $35 \%$ & $16 \%$ & $21 \%$ & $27 \%$ & & & & 0.159 & 0.20 & 0.183 & 0.30 & & \\
\hline MAU43 & $39 \%$ & $22 \%$ & $5 \%$ & $29 \%$ & & $5 \%$ & & 0.220 & n.d. & 0.260 & 0.43 & & \\
\hline MAU44 & $34 \%$ & $21 \%$ & $25 \%$ & $16 \%$ & & $5 \%$ & & 0.453 & n.d. & 0.211 & 0.35 & & \\
\hline MAU45 & $48 \%$ & $10 \%$ & $4 \%$ & $14 \%$ & $15 \%$ & $9 \%$ & & 0.219 & n.d. & 0.131 & 0.22 & & \\
\hline MAU46 & $35 \%$ & $21 \%$ & $20 \%$ & $25 \%$ & & & & 0.211 & 0.32 & 0.148 & 0.25 & & \\
\hline MAU47 & $40 \%$ & $28 \%$ & $4 \%$ & $28 \%$ & & & & 0.279 & 0.47 & 0.259 & 0.43 & & \\
\hline MAU48 & $37 \%$ & $20 \%$ & $15 \%$ & $28 \%$ & & & & 0.215 & 0.32 & 0.215 & 0.35 & 8.938 & 88 \\
\hline MAU49 & $54 \%$ & $13 \%$ & $17 \%$ & $14 \%$ & & $2 \%$ & & 0.275 & n.d. & 0.196 & 0.32 & & \\
\hline MAU50 & $39 \%$ & $20 \%$ & $9 \%$ & $18 \%$ & & $15 \%$ & & 0.348 & n.d. & 0.220 & 0.36 & & \\
\hline MAU51 & $26 \%$ & $36 \%$ & $15 \%$ & $23 \%$ & & & & 0.244 & 0.39 & 0.227 & 0.37 & & \\
\hline MAU52 & $33 \%$ & $22 \%$ & $16 \%$ & $24 \%$ & & $5 \%$ & & 0.243 & n.d. & 0.218 & 0.36 & & \\
\hline MAU53 & $48 \%$ & $9 \%$ & $5 \%$ & $38 \%$ & & & & 0.171 & 0.23 & 0.314 & 0.51 & & \\
\hline MAU54 & $45 \%$ & $16 \%$ & $15 \%$ & $24 \%$ & & & & 0.184 & 0.26 & 0.182 & 0.30 & & \\
\hline MAU56 & $33 \%$ & $23 \%$ & $15 \%$ & $28 \%$ & & & & 0.354 & 0.64 & 0.250 & 0.41 & 8.999 & 39 \\
\hline
\end{tabular}


Table 3

\begin{tabular}{|c|c|c|c|c|c|c|c|c|c|c|c|c|c|}
\hline & & \multicolumn{6}{|c|}{ Parageneses } & \multicolumn{2}{|c|}{ Illite/Muscovite } & \multicolumn{2}{|c|}{ Chlorite } & & \\
\hline Sample & Qtz & Fsp & Chl & Ill/Mus & Act & $\mathrm{Bt}$ & $\mathrm{Pg}$ & FWHM001 & $\mathrm{KI}$ & FWHM002 & $\mathrm{AI}$ & $b_{0}$ & $\% 2 \mathrm{M} 1$ \\
\hline ODU01 & $25 \%$ & $38 \%$ & $11 \%$ & $21 \%$ & & $4 \%$ & & 0.230 & n.d. & 0.209 & 0.34 & & \\
\hline ODU02 & $40 \%$ & $27 \%$ & $14 \%$ & $19 \%$ & & & & 0.390 & 0.72 & 0.230 & 0.38 & & \\
\hline ODU03 & $23 \%$ & $37 \%$ & $10 \%$ & $23 \%$ & & $7 \%$ & & 0.339 & n.d. & 0.220 & 0.36 & $9.020^{*}$ & \\
\hline ODU04 & $39 \%$ & $28 \%$ & $16 \%$ & $16 \%$ & & & & 0.284 & 0.48 & 0.198 & 0.33 & & \\
\hline ODU05 & $37 \%$ & $35 \%$ & $6 \%$ & $18 \%$ & & $4 \%$ & & 0.360 & n.d. & 0.191 & 0.32 & & \\
\hline ODU06 & $29 \%$ & $43 \%$ & $3 \%$ & $20 \%$ & & $4 \%$ & & 0.302 & n.d. & 0.221 & 0.36 & & \\
\hline ODU07 & $34 \%$ & $27 \%$ & $7 \%$ & $26 \%$ & & $7 \%$ & & 0.404 & n.d. & 0.463 & 0.76 & & \\
\hline ODU08 & $35 \%$ & $29 \%$ & $12 \%$ & $20 \%$ & & $5 \%$ & & 0.348 & n.d. & 0.202 & 0.33 & & \\
\hline ODU09 & $43 \%$ & $15 \%$ & $16 \%$ & $21 \%$ & & $5 \%$ & & 0.335 & n.d. & 0.199 & 0.33 & & \\
\hline ODU10 & $29 \%$ & $29 \%$ & $4 \%$ & $29 \%$ & & $9 \%$ & & 0.357 & n.d. & & & & \\
\hline ODU11 & $39 \%$ & $24 \%$ & $12 \%$ & $16 \%$ & & & $10 \%$ & 0.301 & n.d. & 0.239 & 0.39 & & \\
\hline ODU12 & $37 \%$ & $25 \%$ & $14 \%$ & $18 \%$ & & $7 \%$ & & 0.246 & n.d. & 0.189 & 0.31 & & \\
\hline ODU13 & $52 \%$ & $16 \%$ & $3 \%$ & $16 \%$ & & $13 \%$ & & 0.305 & n.d. & 0.240 & 0.39 & & \\
\hline ODU14 & $41 \%$ & $20 \%$ & $3 \%$ & $21 \%$ & & $14 \%$ & & 0.275 & n.d. & 0.152 & 0.25 & & \\
\hline
\end{tabular}


Table 4

\begin{tabular}{|c|c|c|c|c|c|c|c|c|c|c|}
\hline \multirow{2}{*}{$\begin{array}{l}\text { Sample } \mathrm{N}^{\circ} \\
\mathrm{n}\end{array}$} & \multicolumn{2}{|c|}{ MAU26 } & \multirow{2}{*}{$\begin{array}{c}\text { MAU33 } \\
24\end{array}$} & \multirow[b]{2}{*}{ SD } & \multicolumn{2}{|l|}{ ODU09 } & \multicolumn{2}{|l|}{ ODU03 } & \multicolumn{2}{|l|}{ MAU46 } \\
\hline & 42 & SD & & & 7 & SD & 3 & SD & 2 & SD \\
\hline Si & 2.88 & 0.07 & 2.88 & 0.06 & 2.91 & 0.04 & 2.91 & 0.02 & 2.95 & 0.02 \\
\hline $\mathrm{Ti}$ & 0.00 & 0.00 & 0.00 & 0.00 & 0.00 & 0.00 & 0.00 & 0.01 & 0.01 & 0.01 \\
\hline $\mathrm{Al}^{\mathrm{IV}}$ & 1.12 & 0.07 & 1.12 & 0.06 & 1.09 & 0.04 & 1.09 & 0.02 & 1.05 & 0.02 \\
\hline $\mathrm{Al}^{\mathrm{VI}}$ & 1.39 & 0.06 & 1.38 & 0.03 & 1.39 & 0.04 & 1.31 & 0.02 & 1.18 & 0.03 \\
\hline $\mathrm{Fe}^{2+}$ & 2.24 & 0.12 & 2.29 & 0.09 & 2.24 & 0.11 & 2.35 & 0.03 & 2.35 & 0.21 \\
\hline $\mathrm{Mn}$ & 0.01 & 0.02 & 0.01 & 0.02 & 0.01 & 0.03 & 0.04 & 0.01 & 0.00 & 0.00 \\
\hline $\mathrm{Mg}$ & 2.22 & 0.13 & 2.19 & 0.12 & 2.21 & 0.05 & 2.16 & 0.07 & 2.35 & 0.18 \\
\hline $\mathrm{Ca}$ & 0.01 & 0.01 & 0.01 & 0.01 & 0.00 & 0.00 & 0.01 & 0.01 & 0.00 & 0.00 \\
\hline $\mathrm{Na}$ & 0.00 & 0.00 & 0.00 & 0.00 & 0.00 & 0.00 & 0.00 & 0.00 & 0.00 & 0.00 \\
\hline K & 0.00 & 0.01 & 0.00 & 0.00 & 0.00 & 0.01 & 0.01 & 0.01 & 0.01 & 0.02 \\
\hline $\mathrm{Mg} /(\mathrm{Mg}+\mathrm{Fe})$ & 0.50 & 0.03 & 0.51 & 0.02 & 0.50 & 0.02 & 0.48 & 0.01 & 0.50 & 0.04 \\
\hline$T^{\circ} \mathrm{C}$ Inoue & 331 & 37 & 320 & 58 & 294 & 46 & 265 & 72 & 275 & \\
\hline$T^{\circ} \mathrm{C}$ Bourdelle & 187 & 29 & 171 & 10 & 169 & 20 & 189 & 03 & 230 & 13 \\
\hline
\end{tabular}


Table 5

\begin{tabular}{|l|c|c|c|c|c|c|c|c|c|}
\hline Sample & $\mathbf{R}_{\max }$ & Std Dev. & $\mathbf{R}_{\min }$ & Std dev. & $\mathbf{n}$. & $\mathbf{T}_{\mathbf{1}}\left({ }^{\circ} \mathbf{C}\right)$ & $\mathbf{T}_{\mathbf{2}}\left({ }^{\circ} \mathbf{C}\right)$ & $\mathbf{T}_{\mathbf{3}}\left({ }^{\circ} \mathbf{C}\right)$ & $\mathbf{T}_{\mathbf{4}}\left({ }^{\circ} \mathbf{C}\right)$ \\
\hline ODU15 & 6.9 & 0.7 & 2.9 & 0.7 & 30 & 401 & 393 & 286 & 291 \\
\hline RFMV2000 & 7.6 & & 3.15 & & & 414 & 405 & 299 & 299 \\
\hline
\end{tabular}


Figure 1

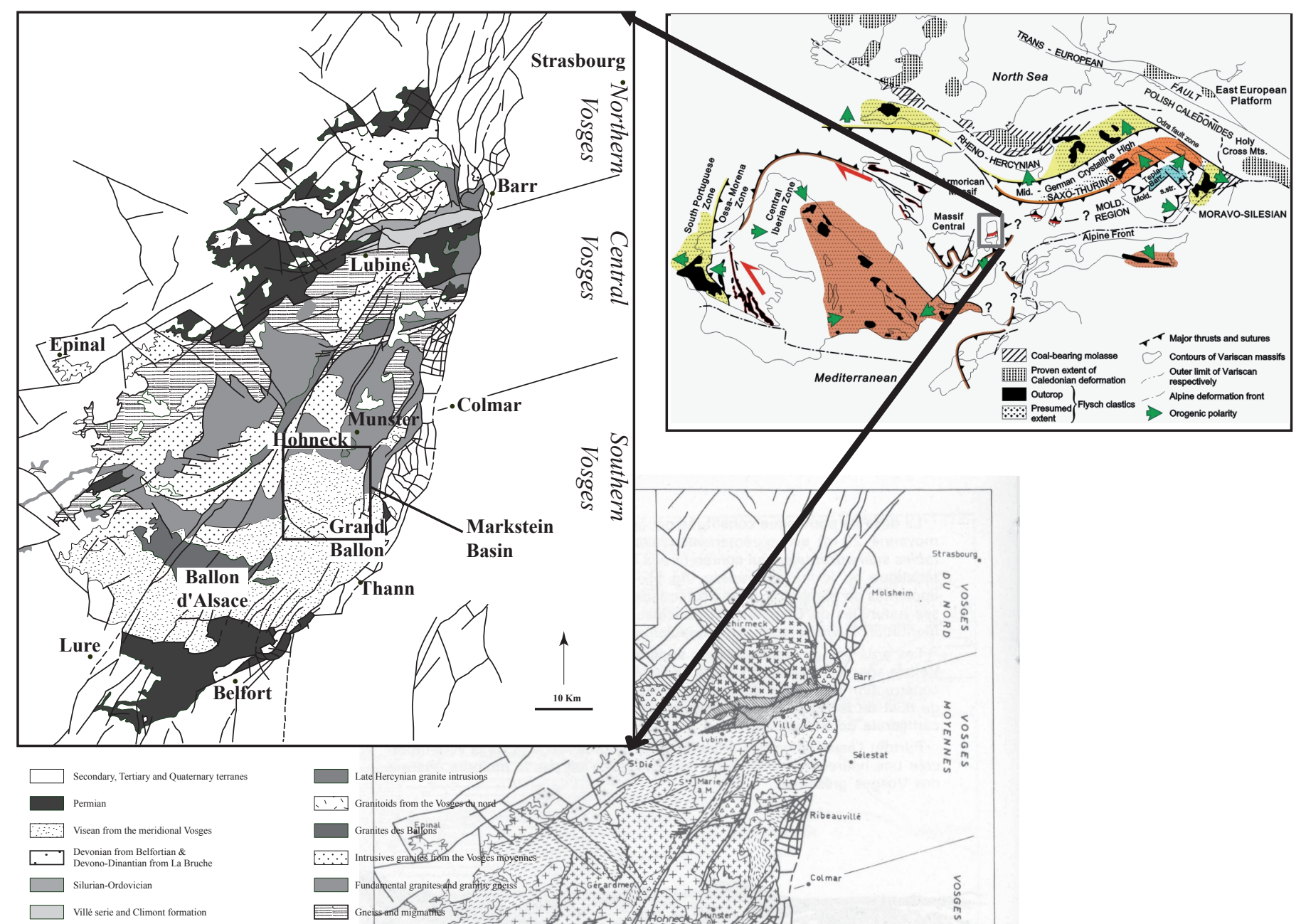


Figure 2

Legend

Bedding strike with dip

- direction and dip angle

- Fault

Locality

$\square$ Dykes

Oderen unit

Markstein unit

Klippen Belt

प1I Thann unit

Granitic rocks

Metamorphic Grade

- Epizone

A High Anchizone

$\triangle$ Low Anchizone

$\square \quad$ Diagenetic Zone

4 Biotite-in zone

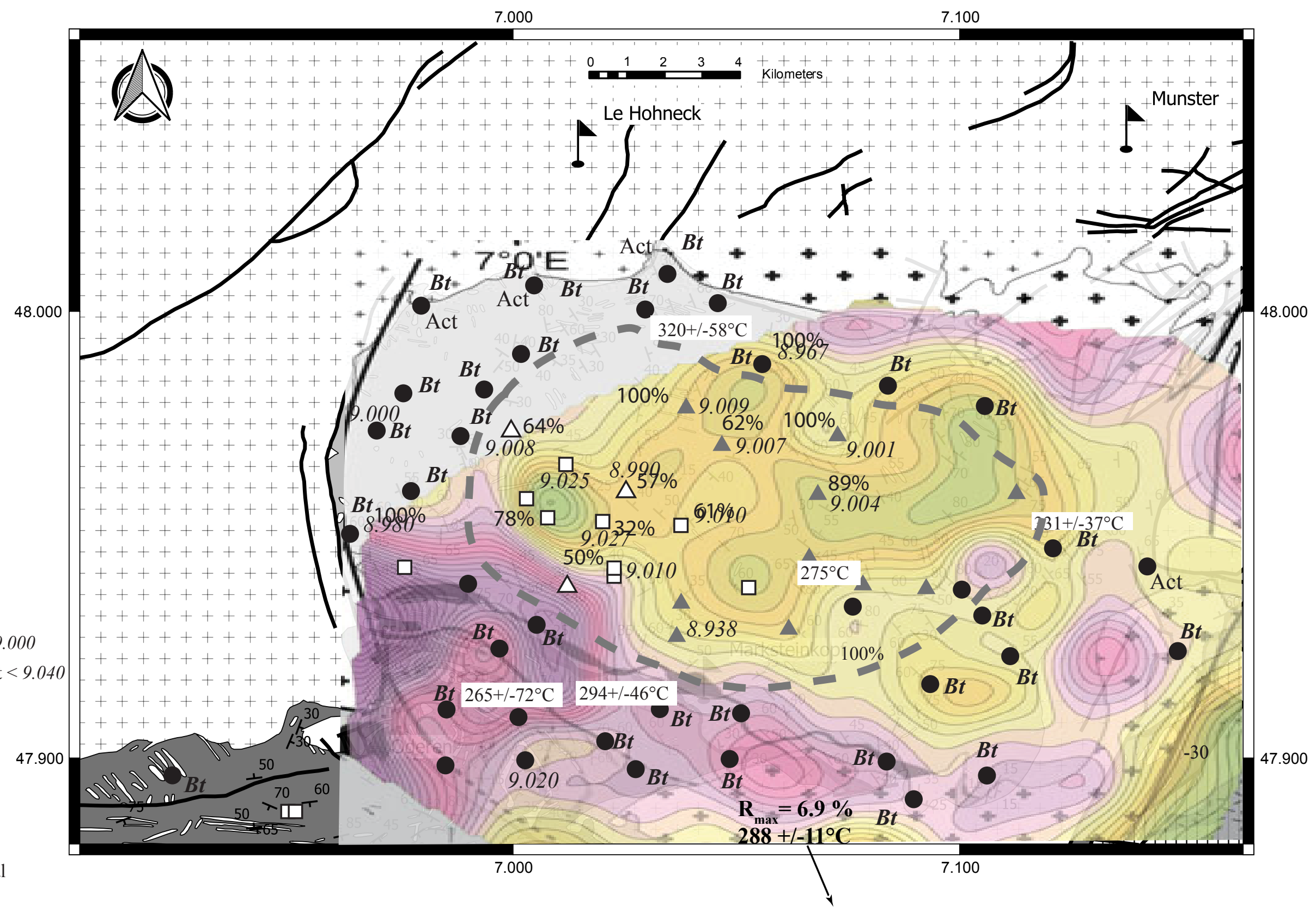


Figure 3

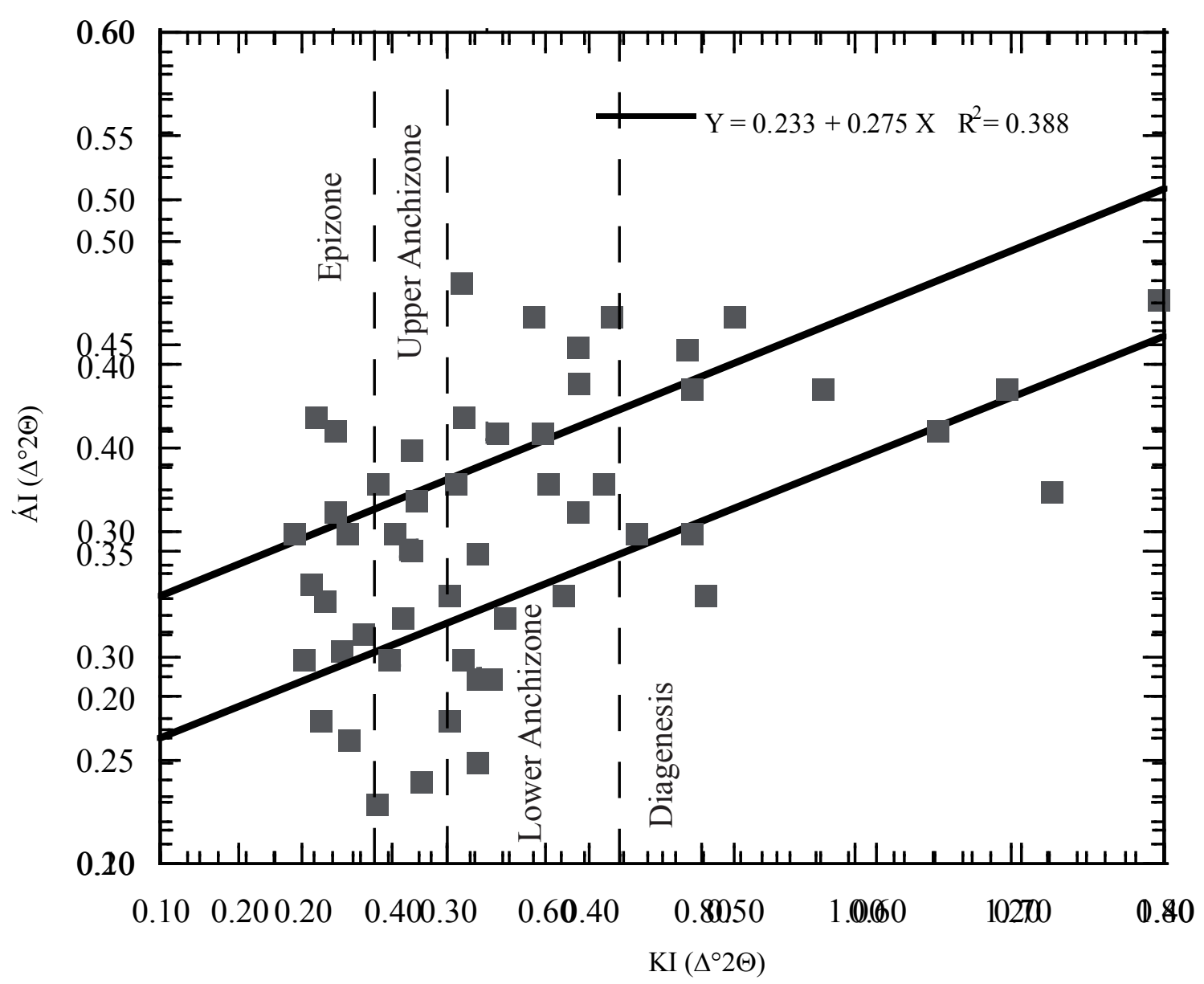


Figure 4

Legend

Bedding strike with dip

$\perp$ direction and dip angle

— Fault

A Locality

$\square$ Dykes

Oderen unit

Markstein unit

Klippen Belt

ШाI Thann unit

$\square$ Granitic rocks

Metamorphic Grade

- Epizone

A High Anchizone

$\triangle$ Low Anchizone

$\square$ Diagenetic Zone

$\% 2 \mathrm{M}_{1}$ polytypes

Biotite-in zone

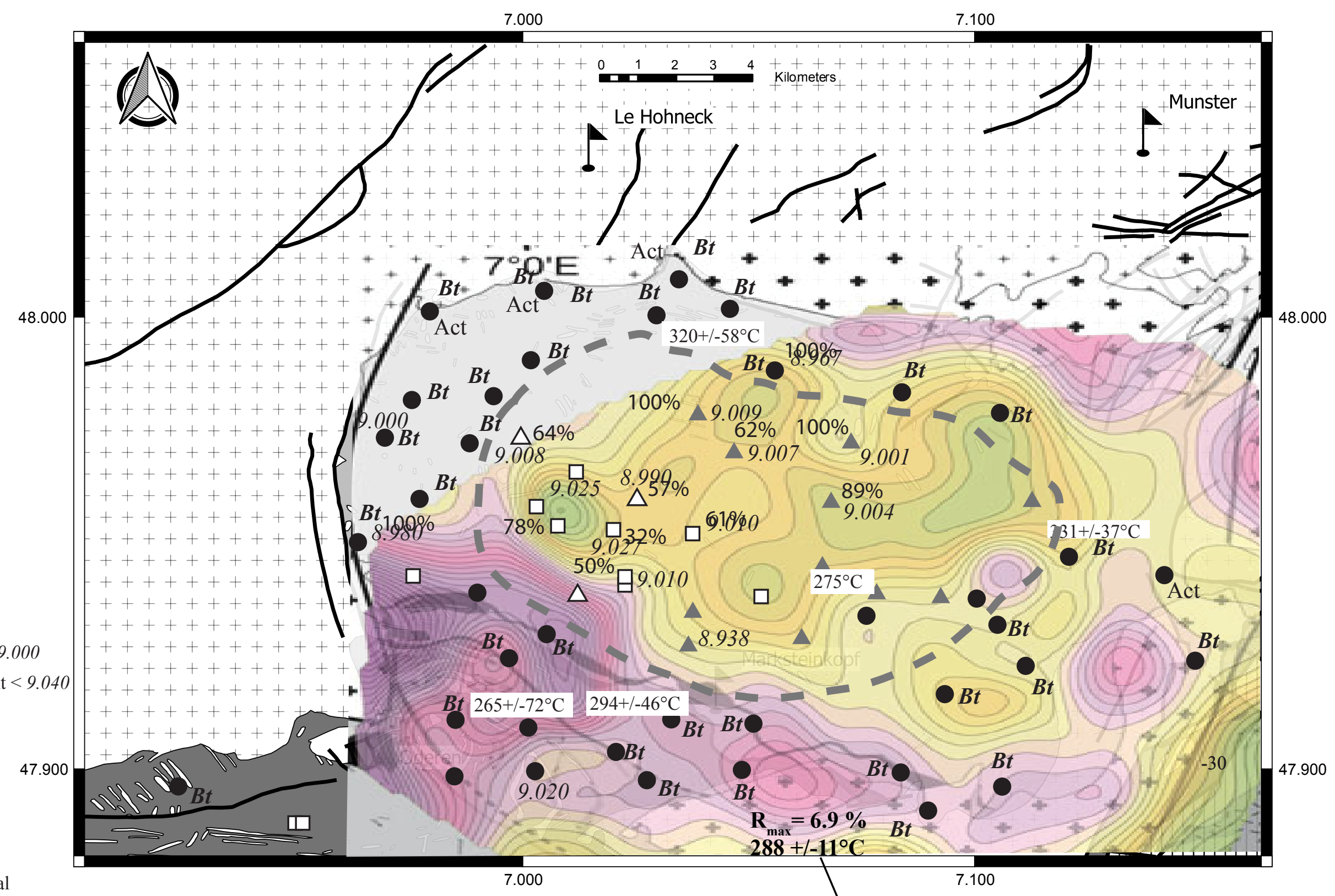


Figure 5

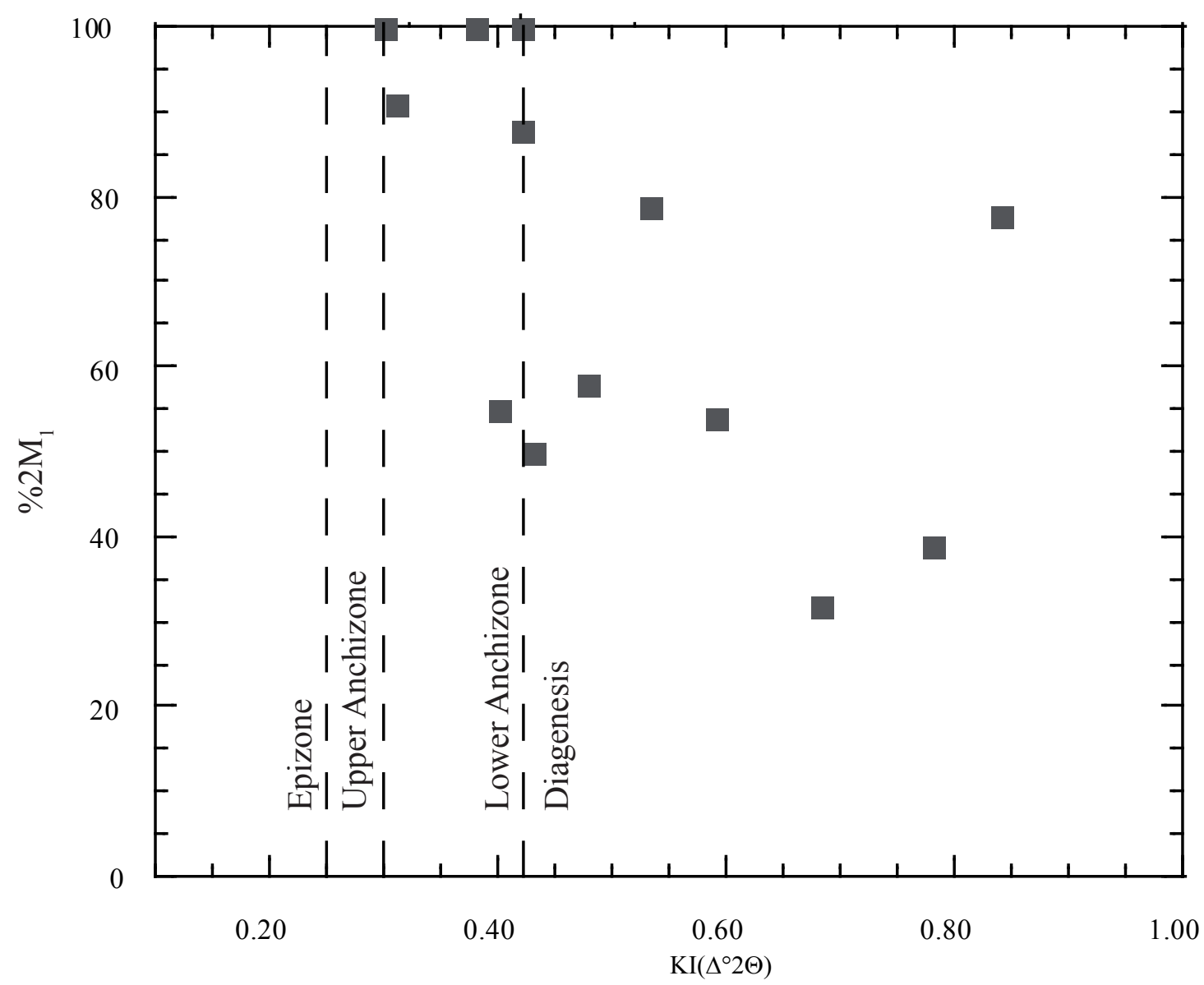


Figure 6

Legend

Bedding strike with dip

$\perp \quad$ direction and dip angle

— Fault

A Locality

$\square$ Dykes

Oderen unit

Markstein unit

Klippen Belt

Ш Thann unit

++- Granitic rocks

Metamorphic Grade

Epizone

- High Anchizone

$\triangle$ Low Anchizone

$\square \quad$ Diagenetic Zone

$8.980<$ Low-pressure gradient $<9.000$ $9.000<$ Medium-pressure gradient $<9.040$ $9.040<$ High-pressure gradient

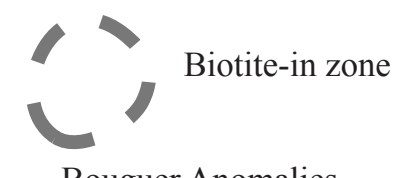

Bouguer Anomalies
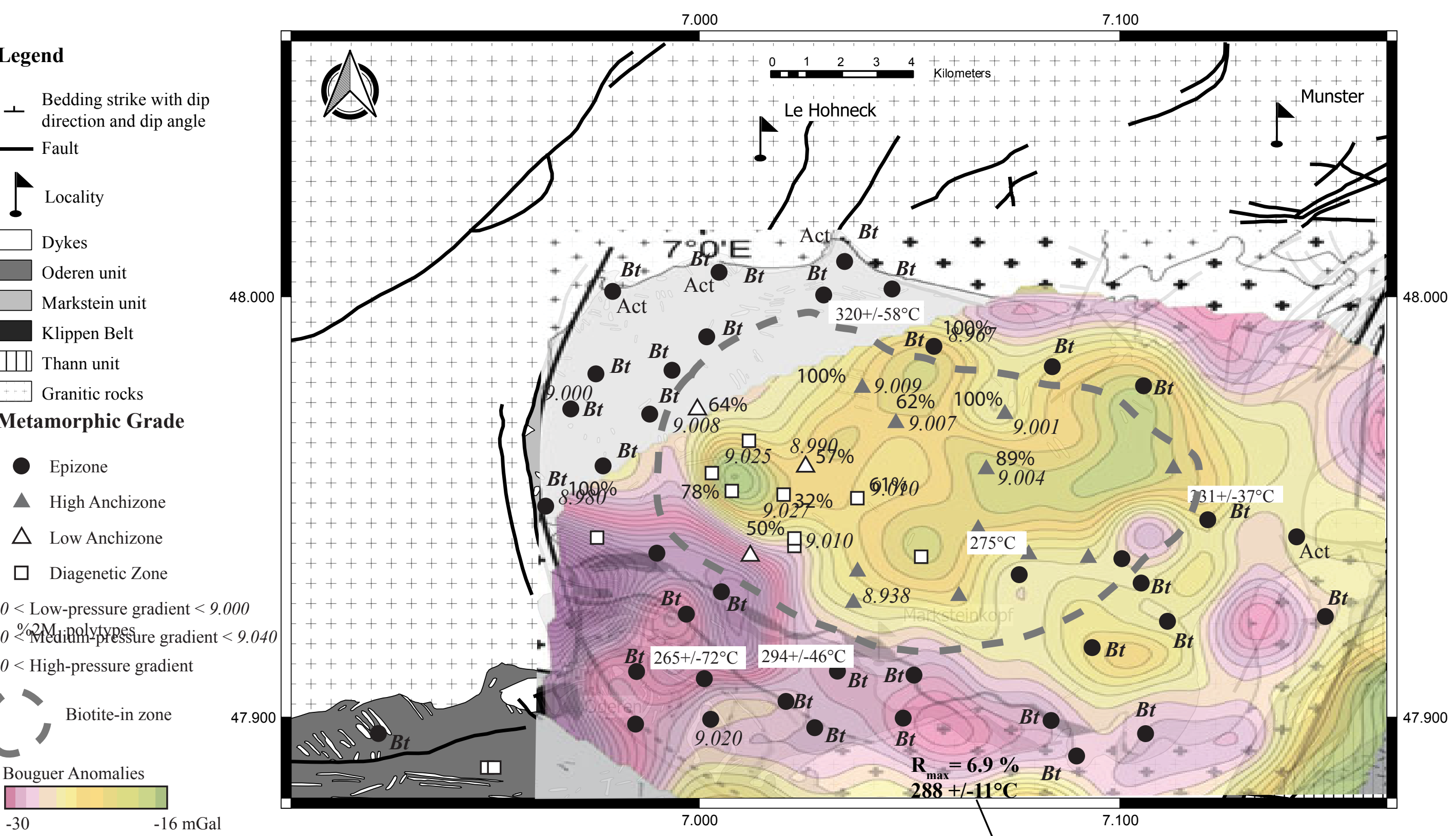